\title{
Yabancılara Özel Amaçlı Türkçe Öğretimi: İktisadi ve İdari Bilimler Fakültesinde Öğrenim Gören Yabancı Uyruklu Öğrenciler İçin İlk 1000 Sözcük Listesi Önerisi*
}

\author{
Mustafa Ulutaş**, Mehmet Kara***
}

Makale Geliş Tarihi: 05.11.2019

Makale Kabul Tarihi: 26.12.2019

DOI: $10.35675 /$ befdergi.477441

$\ddot{O} z$

Türkçenin yabancı dil olarak öğretimi üzerine yapılan çalışmalar son yıllarda büyük hız kazanmıştır. Özellikle Türk Cumhuriyetlerinin bağımsızlıklarını ilan etmeleri üzerine 1992 1993 akademik yılında hayata geçirilen Büyük Öğrenci Projesi, alanla ilgili araştırma sayısının artmasına yol açmıştır. Yapılan araştırmaların büyük çoğunluğu, Türkiye’ye gelen yabancı uyruklu ögrencilerin dil ihtiyaçlarını gidermeye yönelik önemli bilgi, görüş ve materyaller sunmaktadır. Bu çalışmanın amacı, Türkiye'de İktisadi ve İdari Bilimler alanında öğrenim gören yabancılara alanlarında ihtiyaç duyacakları sözcük ve terimlerin listesini sunmaktır. Çalışma betimsel nitelikte olup temel nitel araştırma desenine uygun olarak kurgulanmıştır. Araştırmada veri toplama araçları olarak nitel araştırma yöntemlerinde kullanılan dokümanlar ve yarı yapılandırılmış görüşme formundan yararlanılmıştır. İktisadi İdari Bilimler Fakültesinde Yabancı uyruklu ögrencilerin öğrenim gördüğ̈̈ İktisat, Işsletme, Kamu Yönetimi, Maliye ve Ekonometri bölümlerinin ders programları araştırmada kullanılan dokümanlardir. Bu dokümanlardan elde edilen veriler, betimsel analize tabi tutularak frekans ve yüzdelik değerler elde edilmiştir. Diğer bir veri toplama aracında ilgili programlarda ders veren öğretim üyeleri ile de görüş̧meler yapılmıştır. Belirlenen “illk 1000 Sözcük Listesi” nde yer alan sözcük, sözcük grubu ve terimlerin, ögrencilerin dil ihtiyaçlarını karşılamada ve ilgili alanda yapılacak çalışmalara rehberlik etmede etkili olacă̆ı düşünülmektedir.

Anahtar Kelimeler: Yabancı dil olarak Türkçe ögrretimi, özel amaçlı Türkçe öğretimi, sözcük listesi, İktisadi ve İdari Bilimler

\section{Teaching Turkish For Specific Purposes to Foreigners: The First 1000 Word List Proposal For Foreign Students Who Are Studied In The Faculty of Economics and Administrative Sciences}

\section{Abstract}

Studies on teaching Turkish as a foreign language have gained great speed in recent years. Especially after the Turkish Republics declared their independence, The Great Student Project

\footnotetext{
* Bu çalışma, Gazi Üniversitesi Eğitim Bilimleri Enstitüsünde Doç. Dr. Mehmet Kara danışmanlığında 30.06.2016 tarihinde tamamlanmış olan “Türkiye'de yükseköğrenim görecek yabancilar için özel amaçlı Türkçe öğretimine yönelik program geliştirme: Bir model önerisi”" başlıklı doktora tezinden üretilmiştir.

** Uşak Üniversitesi, Eğitim Fakültesi, Türkçe ve Sosyal Bilimler Eğitimi Bölümü, Uşak, Türkiye, mustafaulutas@gmail.com, ORCID: 0000-0002-8317-7682

${ }^{* * *}$ Gazi Üniversitesi, Eğitim Fakültesi, Türkçe Eğitimi Bölümü, Ankara, Türkiye, fmkr48@gmail.com, ORCID: 0000-0003-4691-5460
}

Kaynak Gösterme: Ulutaş, M. ve Kara, M. (2019). Yabancılara özel amaçlı Türkçe öğretimi: iktisadi ve idari bilimler fakültesinde öğrenim gören yabancı uyruklu öğrenciler için ilk 1000 sözcük listesi önerisi. Bayburt Eğitim Fakültesi Dergisi, 14(28), 467-500. https://doi.org/10.35675/befdergi.477441 
which was realized in 1992-1993 academic year led to an increase in the number of researches related to the field. The majority of the studies include important informations, opinions and materials for troubleshooting language needs of foreign students coming to Turkey. The purpose of this study, to provide a list of words and terms they need in the area to foreigners studying Economics and Administrative Sciences in Turkey. The study is descriptive and it is designed according to the basic qualitative research design. In this research, semi-structured interview form and documents used in qualitative research methods were used as data collection tools. In the Faculty of Economics and Administrative Sciences, the curriculum of the departments of Economics, Business Administration, Public Administration, Finance and Econometrics, where foreign students are studying, are the documents used in the research. The data obtained from these documents were subjected to descriptive analysis and frequency and percentage values were obtained. In another data collection tool, interviews were conducted with the lecturers who gave lectures in related programs. It is thought that the words, phrases and terms in "The First 1000 Words List" determined will be effective in meeting the language needs of the students and guiding the studies in the related field.

Keywords: Teaching Turkish as a foreign language, teaching Turkish for specific purposes, words list, Economics and Administrative Sciences

\section{Giriş}

Bir yabancı dilde uzmanlaşma, günümüzde sadece farklı dil, ülke ve kültürden insanlar arasında duygusal köprüler kurma becerisine sahip olmayı değil, aynı zamanda bireylerin iş ve eğitim hayatında, kendi kariyerlerine ilişkin birtakım hedeflerine ulaşmasında da önemli bir unsuru ifade etmektedir. Bir ya da birden fazla yabancı dilde uzmanlaşma, insanların yaşam kalitelerini artırmada, kültürler ve ülkeler arası ilişkilerde etkin bir hâle gelmelerinde önemli bir rol oynamaktadır. Bilhassa günümüz iş dünyasında veya akademik hayatta bir yabancı dilin özel alanıyla ilgili tüm olanaklarından yararlanabilmek, kişiler arası iletişimdeki başarıyı artırmakta ve büyük bir avantaj sağlamaktadır.

Yaşadığımız çağda küreselleşme, iş gücü piyasalarındaki ve eğitim alanındaki sıkı rekabet, insanların genel ve özel amaçlı yabancı dil öğrenmeye yönelik tutumlarını yeniden gözden geçirmelerine neden olmuştur. Daha fazla dili konuşabilmenin bir kişinin istihdam edilebilirliğini artırmasında, işinde daha kolay ve hızlı yükselebilmesinde, başarılı bir iş hayatının olmasında önemli etkisinin olduğuna yönelik genel görüş, birçok gencin çok dilliliğe öncelik vermesine katkı sağlamaktadır (Davidko, 2011, s.82). Ayrıca, bilhassa uluslararası iş yapan sektörlerde istihdam edilmiş çalışanlar ve onların işverenleri, yabancı bir dilde uzmanlaşmanın sağlayacağı avantajları bizzat tecrübe ederek bu alandaki açıklarını kapatmaya yönelik girişimlerde bulunmaktadır.

İnsanların ihtiyaç duydukları belirli alanlarda geçer dil olarak kabul edilen dili öğrenme istekleri, “özel amaçlı dil öğretimi”nin yaygınlaşmasına yol açmıştır. Günümüz dünyasında, farklı dili konuşan insanların iletişim kurmasında, bilgi 
alışverişini sağlamasında geçer dil İngilizcedir. Buna bağlı olarak özel amaçlı dil öğretimine yönelik çalışmalar da çoğunlukla İngilizce ile ilgili olarak yürütülmektedir (Munby, 1985; Hutchinson ve Waters, 1987; Robinson, 1991; Dudley-Evans ve St John, 2002).

Dil derslerinin öğrenenlerin ihtiyaçlarıyla ilişkili olarak düzenlenmesi eğilimi, özel amaçlı dil kavramının doğmasına zemin hazırlamıştır. Özel amaçlı İngilizce öğretimi yaklaşımı, aşağıda belirtilen bir dizi ihtiyaca tepki olarak ortaya çıkmıştır (Richards, 2001, s.28):

- İngilizce alt yapısına sahip olmayan çok sayıdaki yabancı öğrenciyi Amerikan ve İngiliz üniversitelerinde öğrenim görmeye hazırlama ihtiyac1,

- Genel İngilizce bilgisine sahip, İngilizceyi iş hayatında kullanmak isteyen ama bunun için gerekli iş dili becerisine sahip olmayan doktor, hemşire, mühendis, bilim adamı gibi öğrenenlere öğretim materyali hazırlama ihtiyacı,

- Ticaret amaçlı İngilizce bilgisine gereksinim duyanlara materyal hazırlama ihtiyac1,

- Göçmenlere iş durumları ile başa çıkmak için gerekli dil kullanımını öğretme ihtiyac1.

Özel amaçlı İngilizce öğretiminin kaynağı, dillerin iletişimsel rolü ve işlevsel biçimlerini tanıma amacıyla yakından ilişkilidir. 1920'li yıllarda Prag Dil Bilim Dairesi ve ilgili çalışmalar işlevsel dili, kullanıldığı farklı disiplinler ve durumlarda çeşitli kategorilere ayrılarak tanımlanabilen bir kavram olarak ifade etmiştir. $\mathrm{Bu}$ tanım, bütün dillerin kendine özgü ve farklı alanlara ilişkin özel unsurlarının bulunduğunu ortaya koymuştur. 1930'larda Alman dil bilimciler Fachsprachen (Teknik Dil) kavramını tanıtmışlar, 1950'li yılların başında da Savory, The Language of Science'yi (Bilim Dili) yayımlamıştır. Daha sonraları "belirli amaçlı dil öğretimi" olarak adlandirılacak olan özel amaçlı dil teorisinin temellerini atan Its Growth, Character and Usage (Gelişimi, Karakteri ve Kullanımı) adlı eser 1953 yılında yayımlanmıştır. 1970'li yıllara kadar dil bilimciler özel amaçlı dil kavramının bilim, teknoloji, ekonomi, yönetim, tıp, hukuk, medya, vb. alanlarda bireysel ihtiyaçları karşıladığını kabul etmişlerdir. Bu cümleden hareketle özel amaçlı dil kullanım alanlarının, genel amaçlı dil kullanımına nispeten daha fazla olduğunu söylemek mümkündür (Galova, 2007, s.2).

Özel amaçlı İngilizce öğretimi ile ilgili olarak birçok farklı tanıma ulaşmak mümkündür. Özel amaçlı İngilizce öğretimini bir ürün değil bir yaklaşım olarak gören Hutchinson ve Waters'in görüşleri en önemli tanımlardan biri olarak kabul edilmektedir. Hutchinson ve Waters (1987, s.19) özel amaçlı İngilizce öğretimini, öğrenen ihtiyaçlarına dayalı bir öğrenme yaklaşımı olarak ifade etmektedir. $\mathrm{Bu}$ yaklaşımın temeli "Öğrenenler bir yabancı dili öğrenmeye neden ihtiyaç duyarlar?" sorusudur. $\mathrm{Bu}$ öğretim yaklaşımı, içerik ve yöntemin öğrenenlerin öğrenme amaçlarına göre oluşturulduğu bir yaklaşımdır. 
Konuyla ilgili bir başka önemli çalışmaya imza atan Dudley-Evans ve St John (2002, s.4-5), özel amaçlı İngilizce öğretiminin "kesin” ve “değişken” özelliklerini şu şekilde sıralamaktadır:

$\underline{\text { Kesin özellikler }}$

1. Özel amaçlı İngilizce öğretimi; öğrenenlerin özel ihtiyaçlarını karşılamak şeklinde tanımlanmaktadır;

2. Hizmet ettiği disiplinin temel metodoloji ve faaliyetlerini kullanır;

3. Dil bilgisi, sözcük bilgisi, çalışma, söylem ve tür becerilerine uygun aktivitelerle dil öğretimini merkeze alır.

Değișken özellikler

1. Özel amaçlı İngilizce öğretimi; özel disiplinler tarafından tasarlanabilir ya da bu disiplinlerle ilişkilendirilebilir;

2. Özel öğretim ortamlarında kullanılabilir, genel İngilizce öğretiminden farklı metodoloji benimseyebilir;

3. Lisansüstü öğretim veya profesyonel iş durumlarında yetişkin öğrenenler için düzenlenmesi daha muhtemeldir;

4. Genellikle orta veya ileri düzey öğrenenler için tasarlanır;

5. Çoğunlukla dilin temel bilgilerini ele alır.

Yine Perren'e (1974) göre özel amaçlı İngilizce öğretimi, özel bir alanda ihtiyaç duyulan dil kullanım biçimlerinin, dil becerilerinin kazandırılmasını ifade etmektedir. Perren ayrıca, özel amaçlı İngilizce öğretimini tanımlanmış bir çerçeve, görev veya meslek grubu içinde ihtiyaç duyulan tüm gereksinimleri karşılamak için seçilen kısıtlı bir sözcük ve ifadeler listesi olarak açıklamaktadır (aktaran Adewumi ve Owoyemi, 2012).

Robinson da (1991, s.3), özel amaçlı İngilizce kavramını 1) öğrencilerin İngiliz dili ya da kültürüne ilgi duydukları için değil, eğitim veya çalışmak amacıyla İngilizceye ihtiyaç duydukları için hedefe yönelik bir süreç ve 2) özel amaçlı İngilizce eğitimi alan öğrenenlerin sınırlı bir zamanda başarmayı hedefledikleri bir dizi dilsel yeterlilikleri, işle ilgili homojen ortamlarda ya da öğrencilerin uzmanlaşmayı istedikleri alana ilişkin konuları özel olarak oluşturulmuş sınıflarda belirlemek amacıyla yapılan ihtiyaçlar analizi olarak iki temele oturtmaktadır.

Özel amaçlı İngilizce öğretiminde "amaç", mesleki ve akademik hedefleri başarmada kullanılabilecek bir dil yetisine sahip olmayı ifade etmektedir. Özel amaçlı İngilizce, genel olarak öğrenenlerin dili kullanmaya ne için ihtiyaç duydukları üzerine yoğunlaşan ve bu ihtiyaçları karşılamak için derslerin tasarlandığı eğitimsel bir kavram olarak kabul edilmektedir. İhtiyaca göre sınırlandırılmış dil yeterliliklerinin kazandırılmaya çalışıldığı bu dersler, öğrenenlerin olası dil ihtiyaçlarını karşıladığ derecede başarılı kabul edilmektedir. Özel amaçlı İngilizce öğretiminde betimsel bir 
terim olan "amaç", genel amaçlı İngilizce öğretiminde "Gelecekte dili kullanma becerisini sergileyebilmek için neler kazandırılmalıdır?" sorusuna cevap arayan kuramsal bir kavramdır. Genel amaçlı İngilizce, özel durumlardaki görevlerin üstesinden gelmek için oluşturulmuş sınırlı dil becerisine yönelik bir öğretimi değil, dilin genel kullanımında ortalama bir kapasiteye sahip olmak için gerekli öğretimi içerir. Kısacası özel amaçlı İngilizce öğretimi, öğrenenlerin belli durumlarda gereksinim duyacakları dil yetilerinin önceden yapılan ihtiyaç analizleriyle tespit edilip buna göre öğretimin yapıldığı bir öğretim türü; genel amaçlı İngilizce öğretimi ise gelecekteki olası durumların tanımlanmadan genel dil kullanım kapasitesinin pedagojik bir kuramla geliştirilmeye çalışıldığı öğretim türüdür (Widdowson, 1983, s.6).

Son yıllarda Türkiye'de özel amaçlı dil öğretimine yönelik çalışmaların yapıldığı görülmektedir. Özel amaçlı dil öğretimi, temel olarak akademik ve mesleki dil ihtiyaçlarının karşılanmasına yönelik bir alandır. Özel amaçlı dil öğretiminin özellikle "akademik" dalına bağlı olarak "Akademik Türkçe" ile ilgili araştırmaların hız kazandığı dikkat çekmektedir (Demir, 2017; Dolmacı, 2015; Ekmekçi, 2017; Şen, 2015; Tüfekçioğlu, 2018; Yahşi-Cevher ve Güngör, 2015). Bunun yanında Türkçenin mesleki amaçlı öğretimi üzerine yapılan çalışmaların da olduğu göze çarpmaktadır (Çangal ve Başar, 2016; Çangal ve Yörüsün, 2017; Temizyürek, Çangal ve Yörüsün, 2015). Dolmacı (2015) ve Tüfekçioğlu'nun (2018) çalışmaları, Türkçenin akademik amaçlı öğretiminde söz varlığı üzerine yoğunlaşmakta ve bu çalışmalarda derlem tabanlı sözcük listeleri sunulmaktadır. Bir dilin belirli bir amaç doğrultusunda öğretimi için sözcük listeleri önemli bir yer tutmaktadır. İlgili araştırmalar, Türkçenin yabancılara özel amaçlı öğretiminde akademik alanlara özgü sözcük listelerinin hazırlanmasının önemini ortaya koymaktadır. Hazırlanacak sözcük listeleri, geliştirilecek programlar ve materyaller için önemli veriler sağlayacaktır. Özel amaçlı Türkçe öğretiminde daha özel alanlarda öğretim yapılabilmesi için bu alanlara yönelik (Tıp Türkçesi, İktisat Türkçesi, Eğitim Bilimleri Türkçesi gibi) kavram ve terimlerin belirlenmesi önem arz etmektedir.

$\mathrm{Bu}$ çalışma, yukarıda ifade edilenlerden hareketle Türkiye'de İktisadi ve İdari Bilimler alanında öğrenim gören yabancılara alanlarında ihtiyaç duyacakları sözcüklerin listesini sunması bakımından önemli görülmektedir. Hazırlanan ilk 1000 sözcük listesinde yer alan kavram ve terimlerin, alana özgü metinlerle öğretilmesinin öğrencilerin dil ihtiyaçlarını karşılamada etkili olacağı düşünülmektedir.

\section{Sinırlılıklar}

Çalışmanın verileri; Uşak Üniversitesi İktisadi ve İdari Bilimler Fakültesi İktisat, İşletme, Kamu Yönetimi, Maliye ve Ekonomi bölümlerinin ders içerikleri; bu bölümlerin ortak derslerini yürüten 5 öğretim üyesi; öğretim üyelerinin önerdiği ders materyallerinden elde edilmiştir. İlgili fakülte, dersler, öğretim üyeleri ve materyaller çalışmanın sınırlılığını oluşturmaktadır. 


\section{Yöntem}

Türkiye'de İktisadi ve İdari Bilimler Fakültesinde öğrenim gören yabancılara alanlarında ihtiyaç duyacakları sözcük ve terimlerin listesini sunmayı amaçlayan bu araştırma, betimsel nitelikte olup nitel araştırma yöntemlerine uygun olarak kurgulanmıştır. Nitel araştırmalar, bir kişi, olay, ya da durumun kendine özgü yöntemlerle anlamayı ve keşfetmeyi amaçlayan çalışmalardır (Neuman, 2014). Bu araştırmalarda genellikle dokümanlar, görüşmeler, odak gruplar, katılımcı gözlem gibi yöntemlerle incelenen olgu hakkında bilgiye ulaşılır (Merriam, 2009). Bu çalışmada da öncelikle dokümanlar (ders programları) incelendiği, ardından dokümanlarla ilgili ders veren kişilerle (öğretim üyeleri) görüşmeler benimsendiğinden nitel araştırma yöntemi uygun görülmüştür.

Öğretim üyelerinin derslerinde kullandıkları ve tavsiye ettikleri kaynak kitaplardaki alana özgü sözcük, sözcük grubu ve terimlerin çeşitliliğini ve bunların kitaplardaki sıklık dağılımını belirleyebilmek amacıyla sözcük havuzu oluşturmaya yönelik bir çalışma yapılmıştır. Özel amaçlı dil öğretiminde bu çalışmalar, çoğunlukla derlem ya da kesit çözümlemesi şeklinde yürütülmektedir. Derlem araştırmaları, dilin değişken yapılarını birçok dilsel yaklaşıma göre daha kapsamlı bir şekilde anlamamıza yardımcı olur. Örneğin konuşma dili ile ilgili yapılan bir derlem araştırması, dil bilgisi temelli yazılı dilde yer almayan birtakım özel dil yapılarını yansıtabilmektedir. Yine akademik ya da belirli bir alana özel metinlerde yer alan yaygın sözcüklerin listesini çıkarmakta önem taşımaktadır (Conrad, 2004, s.69). Alınyazında "kesit çözümlemesi" (register analysis) olarak ifade edilen ve dil değişkenlerinin tanımlanmasına olanak sağlayan dilsel yaklaşım, kabul gören en eski yaklaşımlardan birisidir; "bu çalışmalar farklı dil kesitlerindeki dilsel özelliklerin düşük ya da yüksek kullanım sıklığıyla ilgili sahip olduğumuz içgüdüsel ya da izlenimsel kanıların deneysel olarak doğrulanmasını ya da çürütülmesini sağlamaktadır." (İnce-Özyıldırım, 2010, s.24). Kesit kavramı; hukuki kesit, bilimsel kesit ya da bürokratik kesit olarak adlandırabileceğimiz dil kullanım alanları ile ilişkili dilsel yapıları ifade etmektedir. Akademik yazı dili ile ilgili yapılan çok boyutlu kesit çözümlemeleri, akademik konuşma ve yazma dili ile ilgili kapsamlı dil bilimsel bilgiler sunmakta ve genel akademik yazı dilinin doğal bilimler, tıp, sosyal bilimler gibi alt disiplinlerine ilişkin gerçekçi tanımlar yapılmasına olanak sağlamaktadır (Biber, 2006, s.11- 12).

\section{Çalışma Grubu}

Çalışmada, incelenen alana özgü dokümanların yanı sıra görüşleri alınan Uşak Üniversitesinde bu alanda çalışan öğretim üyeleri, araştırmanın çalışma grubunu oluşturmaktadır. Araştırma İktisadi ve İdari Bilimler Fakültesinde öğrenim gören öğrencilere odaklandığı için çalışma grubu, amaçlı örnekleme yoluyla sadece ilgili fakültede görev yapan kişilerden seçilmiştir. Amaçlı örnekleme; incelenen fenomeni ayrıntılı bir şekilde keşfetmek amacıyla belirli özelliklere ya da duruma özgü nitelikleri taşıyan katılımcıları seçmek için kullanılan bir yöntemdir (Frost, 2011, 
s.43). Çalışmaya katılan öğretim elemanlarının tamamı İktisadi ve İdari Bilimler Fakültesinde görev yapmaktadır ve öğretim üyesi statüsündedir. İşletme derslerine giren ve uzmanlık alanını yönetim organizasyon (stratejik yönetim, örgütsel davranış,) olarak belirten öğretim üyesi 15 yıl; maliye derslerine giren ve uzmanlığı kamu maliyesi, mali hukuk olan öğretim üyesi 13 yıl; iktisat derslerine giren ve uzmanlık alanını iktisadi gelişme ve uluslararası iktisat olarak ifade eden öğretim üyesi 6 yıl; idare hukuku, çevre hukuku, anayasa hukuku alanlarında uzman olup hukuk derslerine giren öğretim üyesi 3 yıl; genel muhasebe alanında uzman olup bu dersi yürüten öğretim üyesi ise 13 yıllık ders verme tecrübesine sahiptir.

\section{Verilerin Toplanması ve Analizi}

\section{Dokümanlar}

Çalışmada, Uşak Üniversitesi İktisadi ve İdari Bilimler Fakültesinde bulunan bölümlerin ders programlarının incelendiği doküman incelemesi yapılmıştır. "Doküman incelemesi, araştırılması hedeflenen olgu veya olaylar hakkında bilgi içeren yazılı materyallerin analizini kapsar.” (Yıldırım ve Şimşek, 2016, s.189). Yabanc1 uyruklu öğrencilerin öğrenim gördüğü İktisat, İşletme, Kamu Yönetimi, Maliye ve Ekonometri bölümlerinin ders programları ilgili bölümlerden temin edilmiş ve detaylı bir incelemeye tabi tutulmuştur. Yapılan tarama sonucunda bu bölümlerin tümünde İktisada Giriş, Hukuka Giriş, İşletme, Genel Muhasebe ve Kamu Maliyesi derslerinin okutulduğu görülmüş, içeriğin bu ortak dersler üzerinden oluşturulmasının uygun olacağ1 düşünülmüştür.

Çalışmanın amacına uygun olarak öğretim üyelerinden alınan bilgiler doğrultusunda alana özgü kaynak kitaplar temin edilmiştir. Temin edilen kitaplar, dijital ortama aktarılarak Microsoft Word dosyaları hâline getirilmiştir. Daha sonra kitaplar araştırmacı tarafından tek tek okunmuştur. Okuma işlemi sona erdiğinde kitaplarda yer alan sözcükler, sözcük grupları ve kısaltmaların SPSS 19 paket programına yüklenerek kullanım sıklıklarının belirlenmesi planlanmıştır. Birden fazla sözcükten oluşan kavram veya terimlerin programa yüklenebilmesi ve sıklığının hesaplanabilmesi amacıyla okuma esnasında sözcük gruplarını oluşturan sözcükler arasındaki boşluklar tek tek silinmiştir. Örneğin "açılış envanteri” sözcük grubunun arasındaki boşluk silinerek "açılışenvanteri” şeklinde bir kullanım elde edilmiştir. Kitaplardaki konu başlıkları parçalara ayrılmış, bu parçalara bölüm sonlarında yer alan kısa özetler, değerlendirme soruları ve örnek gazete yazıları dâhil edilmemiştir. Bölümlere ayrılan metin parçaları SPSS 19 paket programına yüklenmiş ve kitaplara göre toplam sözcük, sözcük grubu ve kısaltma sayıları belirlenmiştir.

\section{Görüşmeler}

Çalışmanın verileri "görüşme formu yaklaşımı" dikkate alınarak toplanmıştır. Görüşme formu yaklaşımında "Görüşmeci önceden hazırladığı konu veya alanlara sadık kalarak hem önceden hazırlanmış soruları sorma, hem de bu sorular konusunda daha ayrıntılı bilgi alma amacıyla ek sorular sorma özgürlüğüne sahiptir.” (Yıldırım 
ve Şimşek, 2016, s.132). Uygulanan formun birinci bölümünde öğretim elemanlarının; i) çalıştığı fakülte, ii) öğrenim durumu, iii) ders verme tecrübesi ve iv) uzmanlık alanı ile ilgili sorular yer almaktadır. İkinci bölümde ise; i) derslerde kullanılan okuma materyalleri, ii) alanla ilgili temel kaynaklar ve iii) alana özgü sözcük ve terimler ile ilgili sorulara yer verilmektedir.

\section{Geçerlik ve güvenilirlik}

Nitel bir araştırmada geçerlik ve güvenirliği sağlama yöntemleri nicel araştırmalarda uygulanan prosedürlerden farklıdır. Guba ve Lincoln (1985) nitel bir araştırmada iç ve dış geçerliği sağlamanın dört yolundan bahsetmiştir: Bunlar inanırlık, tutarlılık, aktarılabilirlik ve teyit edilebilirliktir. Bu çalışmada iç geçerlik türlerden olan inanırlığı sağlamak için uzman görüşü alınmıştır. Görüşme formu hazırlarken kullanılan sorular, uzman incelemesi (Türkçe eğitimi, program geliştirme, iktisat ve işletme alan uzmanları) yoluyla değerlendirilmiş (Merriam, 2009); hazırlanan görüşme formundaki soruların istenen özelliği ölçüp ölçmediğine bakılmıştır.

\section{Bulgular ve Yorumlar}

Aşağıdaki tabloda "Derslerinizde hangi okuma materyallerini kullanıyorsunuz?" sorusuna verilen cevaplar yer almaktadır.

Tablo 1

Öğretim Üyelerinin Derslerinde Kullandıkları Okuma Materyallerinin Alanlarına Göre Stralamast

\begin{tabular}{|c|c|}
\hline Alan & Kullanılan Materyaller \\
\hline İşletme & Ders kitapları, ders notları, örnek olay, slaytlar ve kısa videolar, köşe yazıları \\
\hline Maliye & Ders kitapları, kaynak kitaplar, makaleler, slaytlar \\
\hline İktisat & Kaynak kitaplar ve ders kitapları \\
\hline Hukuk & $\begin{array}{l}\text { Hukuk Fakültelerinin kitaplarından daha dar kapsamlı çıkarılan İİB'ler için } \\
\text { hazırlanan kısa hukuk kitapları (Kısa İdare, Kısa Anayasa vb.), internet ortamındaki } \\
\text { yargı kararları, bazı hukuk fakültesi hocalarının kaleme aldığı ders notları, pratik } \\
\text { çalışma kitapları }\end{array}$ \\
\hline
\end{tabular}

Muhasebe Ders kitabı (konunun işlenme aşamasında kendi ders notlarımdan da yararlanarak)

Tablo 1'e bakıldığında öğretim üyelerinin çoğunlukla alanlarına yönelik olarak hazırlanmış ders kitapları ve kaynak kitaplardan yararlandıkları görülmektedir. $\mathrm{Bu}$ verilerden hareketle alana özgü sözcük ve terimlerin belirlenmesi aşamasında bu kitaplardan yararlanılmıştır.

Öğretim üyelerine "Çalışmamızda yararlanabilmemiz için alanınızla ilgili genel bilgi ve kavramları içeren temel kaynaklar önerebilir misiniz?" sorusu yöneltilmiştir. $\mathrm{Bu}$ soruya verilen cevaplar Tablo 2'de sunulmaktadır. 
Tablo 2

Ögretim Üyelerinin Derslerinde Kullandıkları ve Önerdikleri Kaynak Kitapların Alanlarına Göre Siralaması

\begin{tabular}{ll}
\hline Alan & Kullanılan ve Önerilen Kitaplar \\
\hline İşletme & Ömer Dinçer ve Yahya Fidan, İşletme Yönetimine Giriş, Alfa Yayınları \\
& Genel İşletme, Açıköğretim Fakültesi Yayınları \\
& M. Şerif Şimşek ve Adnan Çelik, Genel İşletme, Eğitim Akademi Yayınları \\
\hline Maliye & Osman Pehlivan, Kamu Maliyesi \\
& Abdurrahman Akdoğan, Kamu Maliyesi \\
\hline İktisat & Tümay Ertek, Temel Ekonomi \\
& Zeynel Dinler, İktisada Giriş \\
& İktisada Giriş 1 ve İktisada Giriş 2, Açıköğretim Fakültesi Yayınları \\
& İlker Parasız, İktisadın ABC’si \\
\hline Hukuk & Cevdet Atay, Genel ve Temel Hukuk Kavram ve Kurumları \\
& Abdullah Dinçkol, Hukuka Giriş Hukukun Temel Kavramları \\
& Aydın Aybay, Rona Aybay ve Ali Pehlivan, Hukuka Giriş \\
& Hukukun Temel Kavramları, Açıöğretim Fakültesi Yayınları \\
\hline Muhasebe & $\begin{array}{l}\text { Kemalettin Çonkar, Genel Muhasebe } \\
\text { Orhan Sevilengül, Genel Muhasebe }\end{array}$ \\
\hline
\end{tabular}

Tablo 2'de belirtilen kaynak kitaplarla ilgili görüşülen öğretim üyelerine Açıköğretim Fakültesi Yayınları ile ilgili fikirleri sorulmuştur. İktisada Giriş, Hukuka Giriş ve Genel İşletme derslerini yürüten öğretim üyeleri, bu kitapların dilinin daha sade olduğunu, kendi kendine çalışma yöntemine uygun olarak hazırlandıklarından daha anlaşılır olduklarını, alana özgü sözcük ve terimlerin kullanılması açısından kapsamlı olduğunu, bu yüzden derslerinde yararlandıklarını ifade etmişlerdir. Kamu Maliyesi ve Genel Muhasebe derslerinin hocaları bu kitapları öneri listelerinde belirtmemiş olmalarına rağmen diğer öğretim üyelerinin görüşleri kendilerine iletildiğinde derslerinde çok sık yararlanmadıklarını ancak bu eserlerin öğrencilerine kaynak kitaplar olarak önerilebileceğini, bu kitaplardaki metinlerden yararlanılabileceğini ifade etmişlerdir. Buradan hareketle öğretim üyelerinin kullandıkları ve tavsiye ettikleri kitapların yanında derslerle alakalı olarak Açıköğretim Fakültesi Yayınları'ndan çıkan kitaplar da listeye dâhil edilmiş, sözcük sıklığı belirleme aşamasında bunlar da incelenmiştir.

Görüşme formunun son maddesinde öğretim üyelerine "Derslerinizde en s1k kullanılan ve öğrencilerinizin öncelikli bilmesi gereken alana özgü sözcük ve terimlerden kavramlardan birkaçını yazar mısınız?" sorusu yöneltilmiştir. Bu soruya öğretim üyelerinin verdikleri cevaplar Tablo 3'te sunulmaktadır. 
Tablo 3

En Sik Kullanılan ve Öncelikli Bilinmesi Gereken Alana Özgü Sözcük ve Terimlerin Alanlarına Göre Siralaması

\begin{tabular}{ll}
\hline Alan & \multicolumn{1}{c}{ Sözcük/Sözcük Grupları ve Terimler } \\
\hline İşletme & $\begin{array}{l}\text { Ekonomi, pazar, işletme, müteşebbis, kapasite, fizibilite, yönetim, yönetici, finans, } \\
\text { AR-GE }\end{array}$ \\
\hline Maliye & $\begin{array}{l}\text { Muafiyet, istisna, vergiyi doğuran olay, piyasa başarısılığı, devletin ekonomiye } \\
\text { müdahâlesi, verginin konusu, verginin tarhı, verginin tebliği, verginin tahakkuku, } \\
\text { verginin tahsili, verginin beyanı, tam kamusal mal ve hizmetler, dişsallıklar, erdemli } \\
\text { ve erdemsiz mallar, yarı kamusal mal ve hizmetler }\end{array}$
\end{tabular}

İktisat Alternatif maliyet, emek, sermaye, toprak, girişimci, arz, talep, esneklik, piyasa, fayda, tüketici dengesi, üretici dengesi, eş ürün eğrisi, eş maliyet doğrusu, farksızlık eğrileri, bütçe doğrusu, firma dengesi, tam rekabet piyasası, eksik rekabet piyasası

Hukuk

Sorumluluk, ceza, yaptırım, idari fonksiyon, hükûmet, yargı fonksiyonu, yasama fonksiyonu, kural (hukuk kuralları), kuralların uygulanması, özel hukuk, kamu hukuku, iyiniyet, dürüstlük, borç, hukuki muamele, olay, işlem

Muhasebe Gelir, kâr, harcama, gider, zarar, çek, senet, işletme, alış, satış, envanter, bilanço, dönem, dönem sonu, dönen varlıklar, duran varlıklar

Tablo 3'te yer alan sözcük, sözcük grubu ve terimler, oluşturulacak sıklık listesinin yanında alana özgü yaygın sözcük ve terimlerin tespitini amaçlamaktadır. Zira sıklık bakımından ilk sıralarda yer almasa da kullanımı yaygın olan ve alan için önem arz eden sözcüklerin belirlenmesi çalışmanın güvenilirliği açısından önemli görülmektedir. Bununla birlikte yukarıdaki tabloda yer alan sözcük, sözcük gurubu ve terimlerin hemen hemen tamamının oluşturulan sıklık listesinde yer aldığı dikkat çekmektedir.

Çalışmada, öğretim üyelerinin tavsiye ettiği kitaplardan on biri de sözcük havuzu belirleme çalışmasına dâhil edilmiştir. Tüm alanlarda, bu kitaplardan biri Açıköğretim Fakültesi Yayınları'ndan ve diğeri önerilen farklı yayınevlerinden olmak üzere ikişer yayın incelenmiştir. Çalışmaya dâhil edilen kitaplar ve bu kitaplardan alınan toplam sözcük sayıları Tablo 4 'te yer almaktadır.

Tablo 4

Kitaplar ve Kitaplardan Alınan Sözcük Sayıları

\begin{tabular}{lc}
\hline Kitabın Adı & Kitaptan Alınan Sözcük/Sözcük Grubu/Kısaltma Sayısı \\
\hline Genel Muhasebe & 52501 \\
Genel İşletme & 50332 \\
Genel Hukuk & 39115
\end{tabular}


İktisada Giriş 1

28939

Temel Ekonomi

57879

Kamu Maliyesi AÖF

27549

Genel Muhasebe AÖF

27258

İşletme Yönetimine Giriş

71688

Hukukun Temel Kavramları

47397

İktisada Giriş 2

43704

Kamu Maliyesi

52032

Toplam

Tablo 4'e bakıldığında, çalışmada incelenen kitaplardan yaklaşık 500.000 sözcügün sözcük havuzu oluşturmak için SPSS 19 paket programına yüklendiği görülmektedir. Bundan sonraki aşamada her bir kitaptan çalışmaya dâhil edilen farklı sözcükler, sözcük grupları ve kısaltmaların sıklıkları elde edilmiştir. Aşağıda yer alan Tablo 5 'te bu sayılar gösterilmektedir.

Tablo 5

Çalışmaya Dâhil Edilen Farklı Sözcük Sayısı

\begin{tabular}{|c|c|c|c|c|}
\hline Kitabın Adı & $\begin{array}{l}\text { Çalışmaya Dâhil } \\
\text { Grubu/Kısaltma Sayısı }\end{array}$ & Edilen & Farklı & Sözcük/Sözcük \\
\hline Genel Muhasebe & & 8903 & & \\
\hline Genel İşletme & & 13118 & & \\
\hline Genel Hukuk & & 8924 & & \\
\hline İktisada Giriş 1 & & 8314 & & \\
\hline Temel Ekonomi & & 11069 & & \\
\hline Kamu Maliyesi AÖF & & 11971 & & \\
\hline Genel Muhasebe AÖF & & 6618 & & \\
\hline İşletme Yönetimine Giriş & & 16419 & & \\
\hline Hukukun Temel Kavramları & & 15335 & & \\
\hline İktisada Giriş 2 & & 11312 & & \\
\hline Kamu Maliyesi & & 9235 & & \\
\hline Toplam & & 121218 & & \\
\hline
\end{tabular}

Sözcük havuzu oluşturma çalışmasının bundan sonraki aşamasında kitaplardan elde edilen sözcükler, sözcük grupları ve kısaltmalar detaylı bir incelemeye tabi tutulmuştur. İncelemeye başlamadan önce aynı alana yönelik kitaplardan sözcükler, sözcük grupları ve kısaltmalar aynı tabloda birleştirilmişlerdir. Yani muhasebe, işletme, hukuk, iktisat ve maliye kitaplarından elde edilen veriler toplamda beş dosyada ele alınmıştır. Araştırmacı tarafından ilgili kitapların okunması sonrasında 
konulara ilişkin elde edilen bilgiler ve ayrıca görüşleri alınan alan uzmanı öğretim üyelerinin yardımıyla, ilgili alanın kavramsal içeriğini oluşturmayan, daha çok gündelik dile özgü kullanımları taşıyan sözcükler, sözcük havuzundan elenmiştir. Örneğin incelenen hukuk kitaplarında kullanılan "haber" sözcüğü, alana özgü bir sözcük ya da terim özelliği taşımadığından sözcük havuzuna dâhil edilmezken; "haberleşme hürriyeti” sözcük grubu hukuk alanına özgü bir terim (Türkiye Bilimler Akademisi Türkçe Bilim Terimleri Sözlüğü, 2015) olduğundan sözcük havuzuna alınarak kullanım sıklığı belirlenmiştir. Ortaya çıkan sözcük listeleri incelendiğinde ilgili beş konu alanında kullanılan alana özgü sözcük ve terimlerin büyük oranda örtüştüğü dikkat çekmiştir. Hukuku da dâhil etmek üzere İktisada Giriş, Genel Muhasebe, Genel İşletme ve Kamu Maliyesi alanlarının benzer sözcük ve terim havuzundan beslendiğini söylemek mümkündür. Bunun yanında sözcük ve terimlerin kullanım sıklıkları ve buna bağlı olarak kullanım öncelikleri alandaki önem durumuna göre değişiklik göstermektedir. Örneğin "gayri safi yurt içi hâsıla" terimi hukuk haricindeki tüm alanlarda kullanılmasına rağmen iktisat alanındaki kullanım sıklığı ve önceliği ( $\mathrm{f}=346$, en sık kullanılan 13. terim) ön plana çıkmaktadır. Diğer alanlarda ise kullanım sıklığı ve önceliği olarak çok gerilerde kalmaktadır. Daha önce ilgili beş alandan ortaya çıkan sözcük listelerini birleştirerek tek bir liste oluşturmanın uygun olabileceği düşünülse de her bir alanda yer alan farklı sözcük ve terimlerin de olduğu düşünülerek bu uygulamadan vazgeçilmiştir. $\mathrm{Bu}$ eleme sonrasında ortaya çıkan alanlara özgü sözcük ve terim sayıları aşağıda bulunan Tablo 6'da gösterilmektedir.

Tablo 6

\section{Alanlara Özgü Sözcük ve Terim Sayıları}

\begin{tabular}{lll}
\hline Konu Alanı & Sözcük ve Terim Sayıları & Yüzde değer (f) \\
\hline Muhasebe & 1288 & 11,85 \\
İşletme & 2045 & 18,81 \\
Hukuk & 3470 & 31,93 \\
İktisat & 2185 & 20,10 \\
Maliye & 1881 & 17,30 \\
Toplam & 10869 & 99,99 \\
\hline
\end{tabular}

Sözcük listesi oluşturma çalışmasından elde edilen sonuca göre konu alanlarından toplam 10869 sözcük, sözcük grubu ve terim belirlenmiştir. İşletme, muhasebe, hukuk, iktisat ve maliye alanlarının birbirleriyle olan yakın ilişkisi ve bu disiplinler arasındaki ortaklıklar dikkate alındığında elde edilen 10869 sayısının içerisinde mükerrer sözcük ve terimlerin olduğu yukarıda ifade edilmiştir. Bu sözcük ve terimlerin içerisinden en sık kullanılan belirli sayıdaki sözcük ve terimin belirlenmesi gerektiği düşünülmüş ve ilk 1000 sözcük ve terim (EK) tespit edilmiştir. 10869 söz varlığı arasından ilk 1000 sözcük ve terim, her bir alandan elde edilen sayıların oranları dikkate alınarak belirlenmiş ve sıralama yapıldıktan sonra mükerrer olduğu tespit edilen sözcük ve terimin ilgili alandaki sıklık sıralamasına göre bir sonraki 
sırada bulunan sözcük veya terim listeye dâhil edilmiştir. Birden fazla alanda kullanıldığı görülen sözcük ve terimin hangi konu alanında değerlendirileceğini belirlemede yine kullanım sıklığı dikkate alınmış, ilgili sözcük veya terim oransal olarak en sık hangi alanda kullanılmış ise o konu alanı altında ele alınmıştır. Örneğin “adalet” kelimesi hukuk başlığı altında $28 \mathrm{kez}$, maliye başlığı altında ise $67 \mathrm{kez}$ kullanılmaktadır. Sözcük havuzuna hukuk kitaplarından dâhil edilen toplam sözcük sayıs1 86512, maliye kitaplarından dâhil edilen toplam kelime sayısı ise 79581'dir. Bu durumda hukuk alanı için 28/86512 ve maliye alanı için 67/79581 oranlarını dikkate aldığımızda hukuki bir terim olan "adalet" kavramının maliye başlığı altında daha sık kullanıldığı tespit edilmiştir. Bu bakımdan "adalet” sözcüğünün belirlenen sözcük havuzuna maliye başlığı altında eklenmesi uygun görülmüş, hukuk listesinde de yer alan bu sözcük hukuk listesinden silinerek kullanım sıklığ 1 sırasına göre bir sonraki sözcük bu listeye eklenmiştir. Aşağıdaki tablo, konu alanlarından oranlarına göre ilk 1000 sözcük listesine dâhil edilen sözcük ve terim sayılarını göstermektedir.

Tablo 7

Konu Alanlarından Illk 1000 Sözcük Listesine Dâhil Edilen Sözcük ve Terim Sayısı

\begin{tabular}{lll}
\hline Konu Alanı & Sözcük ve Terim Sayısı & Yüzde değer (f) \\
\hline Muhasebe & 119 & 11,85 \\
İşletme & 188 & 18,81 \\
Hukuk & 319 & 31,93 \\
İktisat & 201 & 20,10 \\
Maliye & 173 & 17,30 \\
Toplam & 1000 & 99,99
\end{tabular}

Tablo 7'de, kitaplardaki sözcük sayıları dikkate alındığında ilk 1000 sözcük listesine alınan sözcük, sözcük grubu ve terimlerin sayısı görülmektedir. $\mathrm{Bu}$ unsurların listede yer alma sayıları bakımından hukuk, iktisat, işletme, maliye ve muhasebe alanları sıralamasını takip ettiği göze çarpmaktadır.

\section{Sonuç ve Öneriler}

Özel amaçlı dil öğretiminde derlem çalışmaları, öğreten ve öğrenenlerin dil ihtiyaçlarını eşleştirmesi bakımından büyük önem taşımaktadır. Derlem çözümlemeleri, dilin sık sık tekrarlanan özelliklerine 1şık tutmaktadır. Belirli bir amaç için hazırlanmış metinlerle ilgili yapılan sıklık çalışmaları, özel amaçlı dil öğretimi sınıflarında kullanılan anahtar sözcükler, dil bilgisi konuları ya da metin yapıları ile ilgili konularda öne çıkan dil unsurlarının temin edilmesi ve ayrıştırılması açısından çok kullanışlı araçlar olarak görülmektedir (Gavioli, 2005, s.5).

Dolmacı (2015) ve Tüfekçioğlu (2018) Türkçenin akademik amaçlı öğretimi; Çangal ve Başar (2016) turizm Türkçesinin öğretimi, Temizyürek ve diğerleri (2015) 
ise iş Türkçesinin öğretimi üzerine yaptıkları çalışmalarda sözcük listesi oluşturmak adına önemli adımlar atmışlardır. Bu çalışmada da özel amaçlı dil öğretiminin akademik dil koluna bağlı olarak İktisadi ve İdari Bilimler Fakültesinde öğrenim gören yabancı uyruklu öğrencilerin sözcük bilgisi ihtiyaçlarını karşılayabilecek "İlk 1000 Sözcük Listesi” hazırlanmıştır. Alana yönelik yapılan bu tarz çalışmalar, Türkiye'ye belirli amaçlarla gelen yabancıların dil öğrenim sürecinde karşılaştıkları birtakım sorunlara çözümler sunması bakımından önemli görülmektedir.

Türkiye'ye öğrenim görmek ya da çalışmak için gelen yabancıların dil ihtiyaçları belirlenerek yapılacak çalışmalar, Türkçenin yabancı dil olarak öğretimine önemli katkılar sağlayacaktır. Bu sözcük ve sözcük grupları ile yapılacak özel amaçlı Türkçe öğretiminde, ilgili alanın metin içerikleri analiz edilerek yapılan bu sözcük listesi hazırlama çalışması, sözcük ve terim öğretiminin daha etkili yapılmasını sağlayacak ve aynı zamanda öğrenenlerin alanlarında daha donanımlı hâle gelmelerine, eğitim ortamında dört dil becerisini daha iyi kullanarak derslerinde ve bilimsel faaliyetlerinde daha başarılı olmalarına yardımcı olacaktır.

$\mathrm{Bu}$ çalı̧̧madan elde edilen sözcük ve sözcük gruplarının dil öğretiminde kullanımı; dil öğrenenlerin yanı sıra fakültedeki öğretim elemanlarına, özel amaçlı dil kursu verenlere ve konuyla ilgili materyal geliştirenlere kolaylık sağlayacaktır. Çünkü ilgili alandaki dil öğrenen öncelikle hangi konuları, sözcük ve sözcük gruplarını öğreneceğini, öğreten ise neleri öğretmesi gerektiğini bilecektir. Bilinçli ve hedefleri belli bir dil öğrenicisi ve öğreticisi her zaman daha başarılı olacaktır.

\section{Kaynakça}

Adewumi, F., O. \& Owoyemi, O., A. (2012). The relevance of English language syllabus for commercial bank workers in Nigeria: An empirical study. American International Journal of Contemporary Research, 2(9), 105-112.

Biber, D. (2006). A corpus based study of spoken and written registers. Holland: John Benjamins.

Conrad, S. (2004). Corpus linguistics, language variation, and language teaching. How to use corpora in language teaching (pp. 67-85). Sinclair, J. M. (Ed.), Holland: John Benjamins.

Çangal Ö. \& Başar, U. (2016). Türkçe öğrenen İranlılar için turizm Türkçesi öğretim programı, terimler sözlüğü kılavuzu denemesi. Turkish Studies, International Periodical for the Languages, Literature and History, 11(3),707-734.

Çangal, Ö. \& Yörüsün, S. (2017). Özel amaçlı Türkçe öğretimi ders kitabı önerisi: Bankacılık Türkçesi. Uluslararası Türkçe Edebiyat Kültür Eğitim Dergisi Sayı: 6/4 2017 s. 2669-2693.

Davidko, N. (2011). A Cognitive approach to teaching English for special purposes (ESP). Studies About Languages, 18(2011), 82-89. 
Demir, D. (2017). Uluslararası öğrencilerin akademik Türkçe ihtiyaçları. Yayımlanmamış doktora tezi. Hacettepe Üniversitesi, Türkiyat araştırmaları Enstitüsü, Ankara.

Dolmacı, M. (2015). Akademik Türkçe kelime bilgisi üzerine bir derlem çalışması: Yabancı dil olarak Türkçe öğretimine dair çıkarımlar. Yayımlanmamış doktora tezi. Gazi Üniversitesi, Eğitim Bilimleri Enstitüsü, Ankara.

Dudley-Evans, T. \& St John, M.J. (2002). Developments in ESP: A multi-disciplinary approach. UK: Cambridge University.

Ekmekçi, V. (2017). Yabancılara Türkçe öğretiminde akademik okuryazarlık öğretimine yönelik bir eylem araştırması. Yayımlanmamış doktora tezi. Erciyes Üniversitesi, Eğitim Bilimleri Enstitüsü, Kayseri.

Frost, N. (2011). Qualitative research methods in psychology: Combining core approaches. USA: Open University Press.

Galova, D. (2007). Languages for specific purposes: Searching for common solutions. UK, Newcastle: Cambridge Scholars.

Lincoln, Y. S., \& Guba, E. G. (1985). Naturalistic Inquiry. Beverly Hills, CA Sage Publications.

Haberleşme özgürlüğü. (2015). Türkiye Bilimler Akademisi Türkçe Bilim Terimleri Sözlüğü içinde. http://www.tubaterim.gov.tr/ sayfasından erişilmiştir.

Hutchinson, T. \& Waters, A. (1987). Specific purposes: A learning-centered approach. USA: Cambridge University.

İnce-Özyıldırım, I. (2010). Tür çözümlemesi: Türkçe metin incelemeleri ve karşılaştırmalar. Ankara: Bilgesu.

Merriam, S. (2009). Qualitative Research: A Guide to Design and Implementation. JosseyBass, San Francisco.

Munby, J. (1985). Communicative Syllabus Design: A socionalinguistic model for defining the content of purpose-specific language programmes (4th printing). Great Britain: Cambridge University.

Neuman, W. (2014). Social Research Methods Qualitative and Quantitative Approaches. UK: Pearson, Essex,.

Richards, J., C. (2001). Curriculum development in language teaching. USA: Cambridge University.

Robinson, P. (1991). ESP today: A practitioner's guide. USA: Prentice Hall International. 
Şen, E. (2015). İktisadi ve idari bilimler Türkçesinin incelenmesi ve yabancı dil olarak Türkçe ögretiminde kullanımı. Yüksek lisans tezi. Dokuz Eylül Üniversitesi, Eğitim Bilimleri Enstitüsü, İzmir.

Temizyürek, F., Çangal, Ö. \& Yörüsün, S. (2015). Yabancılara Türkçe öğretiminde iş Türkçesi öğretim programı, ders kitabı ve terimler sözlüğü denemesi: Bankacılık örneği, Zeitschrift für die Welt der Türken Journal of World of Turks, 7(2), 87-111.

Tüfekçioğlu, B. (2018). Yabancı dil olarak akademik Türkçe: Sosyal bilimlerde akademik ve teknik söz varlığı. Doktora tezi. Hacettepe Üniversitesi, Türkiyat Araştırmaları Enstitüsü, Ankara.

Widdowson, H. G. (1983). Learning purpose and learning use. UK: Oxford University.

Yahşi-Cevher, Ö. \& Güngör, C. (2015). Yabancı dil olarak Türkçe öğretiminde akademik Türkçenin önemine ilişkin uygulamalı bir araştırma: Türk dili öğretimi uygulama ve araştırma merkezi örneği. International Journal of Languages' Education and Teaching, UDES 2015, 2267-2274.

Yıldırım, A. \& Şimşek, H. (2016). Sosyal bilimlerde nitel araştırma yöntemleri (10. baskı). Ankara: Seçkin.

\section{İncelenmiş Alan Kitapları}

Atay, C. (2013). Genel ve temel hukuk kavram ve kurumları. İstanbul: İstanbul Gelişim Üniversitesi.

Aydın, U. \& Sütken, E. (Ed.). (2014). Hukukun temel kavramları (3. baskı). Eskişsehir: Açıöğretim Fakültesi.

Berberoğlu, N. \& Erdoğan, L. (Ed.) (2013). İktisada giriş II (2. bask1). Eskişehir: Açıköğretim Fakültesi.

Çonkar, K., Ulusan, H. ve Öztürk, M. (2014). Genel muhasebe. Afyonkarahisar: Kocatepe Akademi.

Dinçer, Ö. ve Fidan, Y. (2013). Işsletme yönetimine giriş (12. basım). İstanbul: Alfa.

Erdoğan, M. (Ed.). (2012). Genel muhasebe. Eskişehir: Açıköğretim Fakültesi.

Erdoğan, Z. \& Hepkul, A. (Ed.). (2014). Genel işletme. Eskişehir: Açıköğretim Fakültesi.

Ertek, T. (2009). Temel ekonomi. İstanbul: Beta.

Özer, M. \& Tiryaki, A. (Ed.). (2014). İktisada giriş I (4. baskı). Eskişehir: Açıköğretim Fakültesi.

Pehlivan, O. (2014). Kamu maliyesi. Trabzon: Celepler. 
Tosunoğlu, Ş. \& Ergül, Y. T. (Ed.). (2014). Kamu maliyesi (3. baskı). Eskişehir: Açıköğretim Fakültesi.

\section{Ek: İlk 1000 Sözcük Listesi}

\section{Hukuk}

\begin{tabular}{|c|c|c|c|c|c|c|c|}
\hline $\begin{array}{c}\text { Sözcük/ } \\
\text { Terim }\end{array}$ & Siklık & $\begin{array}{c}\text { Sözcük/ } \\
\text { Terim }\end{array}$ & Sıklık & $\begin{array}{c}\text { Sözcük/ } \\
\text { Terim }\end{array}$ & Sıklık & $\begin{array}{c}\text { Sözcük/ } \\
\text { Terim }\end{array}$ & Sıklık \\
\hline $\begin{array}{l}\text { işlem } \\
\text { (hukuki) }\end{array}$ & 654 & düzen & 46 & yasak & 26 & $\begin{array}{l}\text { Türk } \\
\text { Borçlar } \\
\text { Kanunu }\end{array}$ & 18 \\
\hline hak & 606 & menfaat & 46 & $\begin{array}{l}\text { dürüstlük } \\
\text { kuralları }\end{array}$ & 25 & yorum & 18 \\
\hline hukuk & 595 & mülkiyet & 46 & kooperatif & 25 & $\begin{array}{l}\text { yönetsel } \\
\text { yarg1 }\end{array}$ & 18 \\
\hline yasa & 521 & özgürlük & 46 & tescil & 25 & $\begin{array}{l}\text { devletin } \\
\text { uygulama } \\
\text { ürünü }\end{array}$ & 17 \\
\hline anayasa & 436 & yürürlük & 46 & $\begin{array}{l}\text { ticari } \\
\text { işletme }\end{array}$ & 25 & $\begin{array}{l}\text { ahlaka } \\
\text { aykırılık }\end{array}$ & 17 \\
\hline karar & 412 & $\begin{array}{l}\text { borçlar } \\
\text { hukuku }\end{array}$ & 45 & vasiyet & 25 & ayrımcılık & 17 \\
\hline kural & 407 & dernek & 45 & fikra & 24 & $\begin{array}{l}\text { borçlar } \\
\text { kanunu }\end{array}$ & 17 \\
\hline kanun & 381 & idari & 44 & fiil ehliyeti & 24 & $\begin{array}{l}\text { emirler ve } \\
\text { yasaklar }\end{array}$ & 17 \\
\hline yetki & 334 & $\begin{array}{l}\text { medeni } \\
\text { yasa }\end{array}$ & 44 & $\begin{array}{l}\text { hukuka } \\
\text { uygun } \\
\text { fiiller }\end{array}$ & 24 & $\begin{array}{l}\text { güvenlik } \\
\text { tedbiri }\end{array}$ & 17 \\
\hline hüküm & 301 & yönetilenler & 44 & iç tüzük & 24 & hak ehliyeti & 17 \\
\hline $\begin{array}{l}\text { hukuk } \\
\text { kuralı }\end{array}$ & 249 & iddia & 43 & kasit unsuru & 24 & $\begin{array}{l}\text { hukuk } \\
\text { devleti }\end{array}$ & 17 \\
\hline eylem & 241 & milletvekili & 43 & norm & 24 & $\begin{array}{l}\text { idari } \\
\text { yaptırım }\end{array}$ & 17 \\
\hline mahkeme & 233 & $\begin{array}{l}\text { mülkiyet } \\
\text { hakk1 }\end{array}$ & 43 & $\begin{array}{l}\text { yarg1 } \\
\text { çevresi }\end{array}$ & 24 & irade ürünü & 17 \\
\hline özel hukuk & 203 & $\begin{array}{l}\text { özel hukuk } \\
\text { kişisi }\end{array}$ & 43 & zilyetlik & 24 & iş kanunu & 17 \\
\hline ilke & 188 & iptal davası & 42 & disiplin & 23 & kamu gücü & 17 \\
\hline nitelik & 188 & hukuk dalı & 41 & hukuk alanı & 23 & $\begin{array}{l}\text { kişilik } \\
\text { hakları }\end{array}$ & 17 \\
\hline
\end{tabular}




\begin{tabular}{|c|c|c|c|c|c|c|c|}
\hline tüzel kişi & 184 & karine & 40 & temsil & 23 & $\begin{array}{l}\text { maddi zor } \\
\text { kullanma }\end{array}$ & 17 \\
\hline dava & 183 & kusur & 40 & yargilama & 23 & $\begin{array}{l}\text { manevi } \\
\text { unsur }\end{array}$ & 17 \\
\hline koşul & 178 & gerçek kişi & 39 & $\begin{array}{l}\text { yönetsel } \\
\text { yaptırım }\end{array}$ & 23 & mensup & 17 \\
\hline görev & 177 & iptal cezas1 & 39 & $\begin{array}{l}\text { ahlak } \\
\text { kuralları }\end{array}$ & 22 & padişah & 17 \\
\hline $\begin{array}{l}\text { kamu } \\
\text { hukuku }\end{array}$ & 174 & $\begin{array}{l}\text { örf ve âdet } \\
\text { kuralları }\end{array}$ & 39 & $\begin{array}{l}\text { borçlar } \\
\text { yasas1 }\end{array}$ & 22 & $\begin{array}{l}\text { seçim } \\
\text { (yönetsel) }\end{array}$ & 17 \\
\hline madde & 173 & yönetsel & 39 & davalı & 22 & $\begin{array}{l}\text { toplumsal } \\
\text { düzen }\end{array}$ & 17 \\
\hline yaptırım & 165 & $\begin{array}{l}\text { iktidar } \\
\text { (siyasal) }\end{array}$ & 38 & iş veren & 22 & $\begin{array}{l}\text { Türk } \\
\text { Ticaret } \\
\text { Kanunu }\end{array}$ & 17 \\
\hline sözleşme & 160 & $\begin{array}{l}\text { anayasa } \\
\text { hukuku }\end{array}$ & 38 & malik & 22 & $\begin{array}{l}\text { Türkiye } \\
\text { Büyük } \\
\text { Millet } \\
\text { Meclisi iç } \\
\text { tüzüğü }\end{array}$ & 17 \\
\hline irade & 154 & ehliyet & 38 & takdir & 22 & vali & 17 \\
\hline suç & 148 & güvence & 38 & temyiz & 22 & boşanma & 16 \\
\hline üye & 148 & $\begin{array}{l}\text { hukuksal } \\
\text { sonuç }\end{array}$ & 38 & $\begin{array}{l}\text { vergi } \\
\text { hukuku }\end{array}$ & 22 & $\begin{array}{l}\text { common } \\
\text { law (ortak } \\
\text { hukuk) }\end{array}$ & 16 \\
\hline tüzük & 138 & $\begin{array}{l}\text { Resmî } \\
\text { Gazete }\end{array}$ & 38 & $\begin{array}{l}\text { yetkili } \\
\text { organ }\end{array}$ & 22 & doktrin & 16 \\
\hline organ & 134 & $\begin{array}{l}\text { Adliye } \\
\text { Mahkemele } \\
\text { ri }\end{array}$ & 37 & $\begin{array}{l}\text { anayasaya } \\
\text { aykır1lık }\end{array}$ & 21 & $\begin{array}{l}\text { dürüstlük } \\
\text { ilkesi }\end{array}$ & 16 \\
\hline ceza & 123 & değer & 37 & $\begin{array}{l}\text { devlet } \\
\text { organı }\end{array}$ & 21 & eser & 16 \\
\hline yönetmelik & 109 & din kuralları & 37 & fail & 21 & gaiplik & 16 \\
\hline TBMM & 105 & egemen & 37 & hapis cezas 1 & 21 & icra & 16 \\
\hline sorumlu & 104 & taşınmaz & 37 & $\begin{array}{l}\text { İdare } \\
\text { Mahkemele } \\
\text { ri }\end{array}$ & 21 & $\begin{array}{l}\text { kamu } \\
\text { otoritesi }\end{array}$ & 16 \\
\hline $\begin{array}{l}\text { düzenleme } \\
\text { hakları }\end{array}$ & 103 & vakif & 37 & ihlâl & 21 & $\begin{array}{l}\text { kamu } \\
\text { yönetimi }\end{array}$ & 16 \\
\hline $\begin{array}{l}\text { hukuk } \\
\text { düzeni }\end{array}$ & 96 & ahlak & 36 & $\begin{array}{l}\text { İlk Derece } \\
\text { Mahkemele } \\
\text { ri }\end{array}$ & 21 & soyutluk & 16 \\
\hline
\end{tabular}




\begin{tabular}{|c|c|c|c|c|c|c|c|}
\hline yarg1 & 96 & olgu & 36 & medeni & 21 & tek yanlı & 16 \\
\hline $\begin{array}{l}\text { Anayasa } \\
\text { Mahkemesi }\end{array}$ & 95 & onay & 36 & örgütlenme & 21 & $\begin{array}{l}\text { Vergi } \\
\text { Mahkemele } \\
\text { ri }\end{array}$ & 16 \\
\hline $\begin{array}{l}\text { Türk } \\
\text { Medeni } \\
\text { Kanunu }\end{array}$ & 94 & $\begin{array}{l}\text { Roma } \\
\text { Hukuku }\end{array}$ & 36 & öznel & 21 & zamanaşımı & 16 \\
\hline $\begin{array}{l}\text { temel hak } \\
\text { ve } \\
\text { özgürlükler }\end{array}$ & 92 & sistem & 36 & para cezas 1 & 21 & $\begin{array}{l}\text { Adalet } \\
\text { Bakanlığ }\end{array}$ & 15 \\
\hline yasama & 91 & $\begin{array}{l}\text { yokluk } \\
\text { durumu }\end{array}$ & 36 & sigorta & 21 & aleyh & 15 \\
\hline yürütme & 91 & davranış & 35 & temsilci & 21 & $\begin{array}{l}\text { büyükşehir } \\
\text { belediyesi }\end{array}$ & 15 \\
\hline $\begin{array}{l}\text { maddi } \\
\text { unsur }\end{array}$ & 89 & merci & 35 & $\begin{array}{l}\text { Türk } \\
\text { vatandaşlığ }\end{array}$ & 21 & denetleme & 15 \\
\hline $\begin{array}{l}\text { Bakanlar } \\
\text { Kurulu }\end{array}$ & 87 & fiil & 34 & $\begin{array}{l}\text { yönetsel } \\
\text { işlem }\end{array}$ & 21 & $\begin{array}{l}\text { hukuka } \\
\text { uygunluk }\end{array}$ & 15 \\
\hline hâkim & 87 & $\begin{array}{l}\text { hukuki } \\
\text { ilişki }\end{array}$ & 34 & $\begin{array}{l}\text { Askerî } \\
\text { Yargitay }\end{array}$ & 20 & $\begin{array}{l}\text { iki taraflı } \\
\text { kamu } \\
\text { hukuku } \\
\text { işlemi }\end{array}$ & 15 \\
\hline $\begin{array}{l}\text { tazminat } \\
\text { yaptırımı }\end{array}$ & 86 & kamu yararı & 34 & $\begin{array}{l}\text { ceza } \\
\text { kanunları }\end{array}$ & 20 & $\begin{array}{l}\text { insan } \\
\text { hakları }\end{array}$ & 15 \\
\hline usul & 86 & kararname & 34 & $\begin{array}{l}\text { genel } \\
\text { hüküm }\end{array}$ & 20 & ispat yükü & 15 \\
\hline $\begin{array}{l}\text { hukuka } \\
\text { aykırı } \\
\text { davranıs }\end{array}$ & 84 & siyasi parti & 33 & görev alanı & 20 & köle & 15 \\
\hline $\begin{array}{l}\text { Cumhurbaş } \\
\text { kanı }\end{array}$ & 80 & $\begin{array}{l}\text { Ceza } \\
\text { Mahkemesi }\end{array}$ & 32 & $\begin{array}{l}\text { kamu } \\
\text { düzeni }\end{array}$ & 20 & maksat & 15 \\
\hline esas & 75 & $\begin{array}{l}\text { Hukuk } \\
\text { Mahkemesi }\end{array}$ & 32 & sicil & 20 & salt & 15 \\
\hline uyuşmazlık & 75 & nisbî hak & 32 & $\begin{array}{l}\text { Türk Hukuk } \\
\text { Sistemi }\end{array}$ & 20 & $\begin{array}{l}\text { ticaret } \\
\text { hukuku }\end{array}$ & 15 \\
\hline meclis & 73 & topluluk & 32 & $\begin{array}{l}\text { vatandaşlık } \\
\text { hakkı }\end{array}$ & 20 & $\begin{array}{l}\text { Ticaret } \\
\text { Kanunu }\end{array}$ & 15 \\
\hline başvuru & 72 & $\begin{array}{l}\text { uluslararası } \\
\text { antlaşma }\end{array}$ & 32 & yarg1 karar1 & 20 & $\begin{array}{l}\text { Uyuşmazlı } \\
\mathrm{k} \\
\text { Mahkemesi }\end{array}$ & 15 \\
\hline
\end{tabular}




\begin{tabular}{|c|c|c|c|c|c|c|c|}
\hline $\begin{array}{l}\text { kamu tüzel } \\
\text { kişisi }\end{array}$ & 71 & $\begin{array}{l}\text { uluslararas1 } \\
\text { hukuk }\end{array}$ & 32 & yarg1 kollar1 & 20 & $\begin{array}{l}\text { yenilik } \\
\text { doğuran } \\
\text { haklar }\end{array}$ & 15 \\
\hline antlaşma & 70 & yargıç & 32 & $\begin{array}{l}\text { Askerî } \\
\text { Yüksek } \\
\text { İdare } \\
\text { Mahkemesi }\end{array}$ & 19 & $\begin{array}{l}\text { yönetsel } \\
\text { sözleşme }\end{array}$ & 15 \\
\hline hak sahibi & 70 & $\begin{array}{l}\text { Yüksek } \\
\text { Mahkeme }\end{array}$ & 32 & $\begin{array}{l}\text { Cumhuriyet } \\
\text { Başsavcisı }\end{array}$ & 19 & $\begin{array}{l}\text { Alt Derece } \\
\text { Mahkemele } \\
\mathrm{r}\end{array}$ & 14 \\
\hline işlev & 69 & aile hukuku & 31 & davacı & 19 & $\begin{array}{l}\text { Anayasa } \\
\text { değişikliği }\end{array}$ & 14 \\
\hline $\begin{array}{l}\text { kanun } \\
\text { hükmünde } \\
\text { kararname }\end{array}$ & 69 & eşya & 31 & $\begin{array}{l}\text { eşya } \\
\text { hukuku }\end{array}$ & 19 & erginlik & 14 \\
\hline Danıştay & 68 & idari yarg1 & 31 & fiilî & 19 & $\begin{array}{l}\text { Hâkimler } \\
\text { ve Savcılar } \\
\text { Yüksek } \\
\text { Kurulu }\end{array}$ & 14 \\
\hline istisna & 68 & $\begin{array}{l}\text { irade } \\
\text { açıklaması }\end{array}$ & 31 & gerekçe & 19 & $\begin{array}{l}\text { hukuksal } \\
\text { durum }\end{array}$ & 14 \\
\hline iyi niyet & 68 & $\begin{array}{l}\text { örf ve âdet } \\
\text { hukuku }\end{array}$ & 30 & $\begin{array}{l}\text { İslâm } \\
\text { hukuku }\end{array}$ & 19 & $\begin{array}{l}\text { idari } \\
\text { sözleşmeler }\end{array}$ & 14 \\
\hline $\begin{array}{l}\text { hukuk } \\
\text { sistemi }\end{array}$ & 64 & bağlayıcılık & 29 & $\begin{array}{l}\text { kıymetli } \\
\text { evrak }\end{array}$ & 19 & intifa hakk1 & 14 \\
\hline ödev & 63 & eşitlik & 29 & $\begin{array}{l}\text { medeni } \\
\text { hukuk }\end{array}$ & 19 & kabahat & 14 \\
\hline vatandaş & 62 & $\begin{array}{l}\text { idari para } \\
\text { cezas1 }\end{array}$ & 29 & ölçülülük & 19 & k1sitll11k & 14 \\
\hline denetim & 60 & iş hukuku & 29 & $\begin{array}{l}\text { özel } \\
\text { hükümler }\end{array}$ & 19 & kiyas & 14 \\
\hline yarg1 organ1 & 60 & Yargitay & 29 & taşınır & 19 & $\begin{array}{l}\text { Millî } \\
\text { Güvenlik } \\
\text { Kurulu }\end{array}$ & 14 \\
\hline save1 & 59 & $\begin{array}{l}\text { kanun } \\
\text { koyucu }\end{array}$ & 28 & tek taraflilık & 19 & muhatap & 14 \\
\hline daire & 57 & makam & 28 & teşebbüs & 19 & $\begin{array}{l}\text { pozitif } \\
\text { hukuk }\end{array}$ & 14 \\
\hline $\begin{array}{l}\text { hukuk } \\
\text { kaynağ1 }\end{array}$ & 57 & hukuk kişisi & 27 & vekil & 19 & $\begin{array}{l}\text { tam yargı } \\
\text { davaları }\end{array}$ & 14 \\
\hline miras & 57 & $\begin{array}{l}\text { hukuki } \\
\text { sonuç }\end{array}$ & 27 & yarg1 yeri & 19 & tasarruf & 14 \\
\hline
\end{tabular}




\begin{tabular}{|c|c|c|c|c|c|c|c|}
\hline $\begin{array}{l}\text { mutlak } \\
\text { haklar }\end{array}$ & 57 & $\begin{array}{l}\text { iç } \\
\text { düzenleme }\end{array}$ & 27 & $\begin{array}{l}\text { yönetim } \\
\text { hukuku }\end{array}$ & 19 & $\begin{array}{l}\text { tek yanlı } \\
\text { irade } \\
\text { beyanı }\end{array}$ & 14 \\
\hline $\begin{array}{l}\text { kaynak } \\
\text { (referans) }\end{array}$ & 55 & itiraz & 27 & aslî & 18 & $\begin{array}{l}\text { uluslararası } \\
\text { örgütler }\end{array}$ & 14 \\
\hline aykırılık & 54 & $\begin{array}{l}\text { kamu } \\
\text { görevi }\end{array}$ & 27 & aynî haklar & 18 & yetki yasası & 14 \\
\hline özel haklar & 53 & $\begin{array}{l}\text { kamu } \\
\text { hakları }\end{array}$ & 45 & borç ilişkisi & 18 & çatışma & 13 \\
\hline Başbakan & 51 & $\begin{array}{l}\text { kamu } \\
\text { kurum ve } \\
\text { kuruluşları }\end{array}$ & 27 & çelişki & 18 & $\begin{array}{l}\text { görgü } \\
\text { kuralları }\end{array}$ & 13 \\
\hline toplum & 51 & nesnel & 27 & genel kurul & 18 & hakkaniyet & 13 \\
\hline bağımsızlık & 50 & $\begin{array}{l}\text { meslek } \\
\text { kuruluşları }\end{array}$ & 26 & $\begin{array}{l}\text { hukukun } \\
\text { genel } \\
\text { ilkeleri }\end{array}$ & 18 & hukukî olay & 13 \\
\hline $\begin{array}{l}\text { ceza } \\
\text { hukuku }\end{array}$ & 50 & adli yarg1 & 26 & $\begin{array}{l}\text { idare } \\
\text { hukuku }\end{array}$ & 18 & idari işlem & 13 \\
\hline içtihat & 48 & edim & 26 & $\begin{array}{l}\text { miras } \\
\text { hukuku }\end{array}$ & 18 & komisyon & 13 \\
\hline $\begin{array}{l}\text { mal varlığı } \\
\text { hakları }\end{array}$ & 48 & somutlaşma & 26 & statü & 18 & laiklik & 13 \\
\hline talep hakk1 & 47 & $\begin{array}{l}\text { Türk Ceza } \\
\text { Kanunu }\end{array}$ & 26 & tacir & 18 & & \\
\hline
\end{tabular}

\section{İktisat}

\begin{tabular}{|c|c|c|c|c|c|c|c|}
\hline Sözcük/Terim & Sıklık & $\begin{array}{l}\text { Sözcük/ } \\
\text { Terim }\end{array}$ & Sıklık & $\begin{array}{l}\text { Sözcük/ } \\
\text { Terim }\end{array}$ & Sıklık & $\begin{array}{l}\text { Sözcük/ } \\
\text { Terim }\end{array}$ & Sıklık \\
\hline fiyat & 1356 & $\begin{array}{l}\text { fiyatlar } \\
\text { genel } \\
\text { düzeyi }\end{array}$ & 109 & $\begin{array}{l}\text { marjinal } \\
\text { tüketim } \\
\text { eğilimi }\end{array}$ & 52 & olanak & 35 \\
\hline mal & 1016 & $\begin{array}{l}\text { marjinal } \\
\text { fayda }\end{array}$ & 105 & $\begin{array}{l}\text { ekonomi } \\
\text { politikası }\end{array}$ & 51 & $\begin{array}{l}\text { toplam } \\
\text { tüketim } \\
\text { harcamaları }\end{array}$ & 35 \\
\hline firma & 832 & $\begin{array}{l}\text { makroikti } \\
\text { sat } \\
\text { (makroek } \\
\text { onomi) }\end{array}$ & 103 & $\begin{array}{l}\text { mal } \\
\text { miktarı }\end{array}$ & 49 & $\begin{array}{l}\text { üretim } \\
\text { düzeyi }\end{array}$ & 35 \\
\hline
\end{tabular}




\begin{tabular}{|c|c|c|c|c|c|c|c|}
\hline ekonomi & 681 & diş ticaret & 102 & $\begin{array}{l}\text { ölçek } \\
\text { ekonomil } \\
\text { eri }\end{array}$ & 49 & $\begin{array}{l}\text { anonim } \\
\text { şirket }\end{array}$ & 34 \\
\hline üretim & 652 & $\begin{array}{l}\text { toplam } \\
\text { talep }\end{array}$ & 100 & rezerv & 49 & kamu malı & 34 \\
\hline gelir & 553 & fayda & 96 & $\begin{array}{l}\text { sras } \\
\text { (eğrisi) }\end{array}$ & 49 & kitlık & 34 \\
\hline piyasa & 517 & $\begin{array}{l}\text { marjinal } \\
\text { maliyet }\end{array}$ & 95 & marjinal & 48 & $\begin{array}{l}\text { marjinal } \\
\text { fiziki ürün }\end{array}$ & 34 \\
\hline miktar & 479 & varsayım & 95 & iş & 47 & $\begin{array}{l}\text { ekonomik } \\
\text { kriz }\end{array}$ & 33 \\
\hline talep & 463 & $\begin{array}{l}\text { Keynesye } \\
\mathrm{n} \text { görüş }\end{array}$ & 91 & $\begin{array}{l}\text { marjinal } \\
\text { gelir }\end{array}$ & 47 & $\begin{array}{l}\text { fiyat } \\
\text { esnekliği }\end{array}$ & 33 \\
\hline para & 393 & $\begin{array}{l}\text { toplam } \\
\text { fayda }\end{array}$ & 90 & $\begin{array}{l}\text { marjinal } \\
\text { ürün }\end{array}$ & 47 & hâsıla & 33 \\
\hline birim (ölçü) & 384 & değişken & 89 & akım & 46 & kartel & 33 \\
\hline $\begin{array}{l}\text { gayri safi yurt } \\
\text { içi hâsıla }\end{array}$ & 346 & teori & 89 & cari gelir & 46 & likidite & 33 \\
\hline tüketici & 331 & reel & 88 & $\begin{array}{l}\text { işsizlik } \\
\text { oranı }\end{array}$ & 46 & $\begin{array}{l}\text { ödemeler } \\
\text { bilançosu }\end{array}$ & 33 \\
\hline oran & 312 & $\begin{array}{l}\text { denge } \\
\text { gelir } \\
\text { düzeyi }\end{array}$ & 86 & parasal & 46 & $\begin{array}{l}\text { sübvansiyo } \\
\mathrm{n}\end{array}$ & 33 \\
\hline enflasyon & 273 & $\begin{array}{l}\text { gayri safi } \\
\text { millî } \\
\text { hâsıla }\end{array}$ & 84 & $\begin{array}{l}\text { sermaye } \\
\text { stoku }\end{array}$ & 46 & $\begin{array}{l}\text { toplam } \\
\text { talep eğrisi }\end{array}$ & 33 \\
\hline mal ve hizmet & 266 & arz eğrisi & 82 & $\begin{array}{l}\text { bankacil1 } \\
\text { k sistemi }\end{array}$ & 44 & $\begin{array}{l}\text { az } \\
\text { geliş̧sişlik }\end{array}$ & 32 \\
\hline tüketim & 255 & $\begin{array}{l}\text { yatırım } \\
\text { harcamal } \\
\text { arı }\end{array}$ & 82 & inelastik & 44 & getiri oran 1 & 32 \\
\hline işsizlik & 236 & mevduat & 81 & monopol & 44 & $\begin{array}{l}\text { sermaye } \\
\text { malları }\end{array}$ & 32 \\
\hline tasarruf & 228 & ticaret & 81 & $\begin{array}{l}\text { doğal } \\
\text { kaynaklar }\end{array}$ & 43 & alım & 31 \\
\hline işçi & 214 & $\begin{array}{l}\text { toplam } \\
\text { hâsılat }\end{array}$ & 81 & eğimlilik & 43 & nominal & 31 \\
\hline
\end{tabular}




\begin{tabular}{|c|c|c|c|c|c|c|c|}
\hline faiz oranı & 200 & hükümet & 80 & $\begin{array}{l}\text { harcanabi } \\
\text { lir kişisel } \\
\text { gelir }\end{array}$ & 43 & $\begin{array}{l}\text { ortalama } \\
\text { maliyet }\end{array}$ & 31 \\
\hline faktör & 198 & $\begin{array}{l}\text { ekonomi } \\
\text { k büyüme }\end{array}$ & 79 & etken & 42 & $\begin{array}{l}\text { tekelci } \\
\text { firma }\end{array}$ & 31 \\
\hline denge & 190 & pay & 79 & $\begin{array}{l}\text { malın } \\
\text { fiyatı }\end{array}$ & 42 & $\begin{array}{l}\text { ortodoks } \\
\text { politika }\end{array}$ & 30 \\
\hline hane halkları & 178 & $\begin{array}{l}\text { ekonomi } \\
\mathrm{k}\end{array}$ & 78 & $\begin{array}{l}\text { toplam } \\
\text { arz eğrisi }\end{array}$ & 41 & $\begin{array}{l}\text { tüketici } \\
\text { dengesi }\end{array}$ & 30 \\
\hline para arz1 & 175 & iktisat & 78 & $\begin{array}{l}\text { üretim } \\
\text { miktarı }\end{array}$ & 41 & deflasyon & 29 \\
\hline talep eğrisi & 171 & $\begin{array}{l}\text { tam } \\
\text { rekabet } \\
\text { piyasası }\end{array}$ & 78 & veri & 41 & katma değer & 29 \\
\hline esneklik & 170 & $\begin{array}{l}\text { enflasyon } \\
\text { oranı }\end{array}$ & 74 & $\begin{array}{l}\text { fiyat } \\
\text { istikrarı }\end{array}$ & 40 & $\begin{array}{l}\text { kayıtsızlık } \\
\text { eğrisi }\end{array}$ & 29 \\
\hline ihracat & 170 & $\begin{array}{l}\text { tekelci } \\
\text { rekabet } \\
\text { piyasası }\end{array}$ & 74 & $\begin{array}{l}\text { nihai mal } \\
\text { ve } \\
\text { hizmetler }\end{array}$ & 40 & $\begin{array}{l}\text { tüketim } \\
\text { fonksiyonu }\end{array}$ & 29 \\
\hline kısa dönem & 169 & $\begin{array}{l}\text { büyüme } \\
\text { oranı }\end{array}$ & 72 & toprak & 40 & $\begin{array}{l}\text { bütçe } \\
\text { doğrusu }\end{array}$ & 28 \\
\hline uzun dönem & 162 & çarpan & 71 & TÜFE & 40 & $\begin{array}{l}\text { gümrük } \\
\text { tarifesi }\end{array}$ & 28 \\
\hline reel GSYİH & 161 & ikame & 71 & döviz arzı & 39 & $\begin{array}{l}\text { ortalama } \\
\text { toplam } \\
\text { maliyet }\end{array}$ & 28 \\
\hline üretim faktörleri & 160 & $\begin{array}{l}\text { para } \\
\text { talebi }\end{array}$ & 68 & $\begin{array}{l}\text { mikroeko } \\
\text { nomi } \\
\text { (mikroikt } \\
\text { isat) }\end{array}$ & 39 & $\begin{array}{l}\text { tüketim } \\
\text { malları }\end{array}$ & 28 \\
\hline ithalat & 157 & $\begin{array}{l}\text { gelir } \\
\text { düzeyi }\end{array}$ & 67 & $\begin{array}{l}\text { piyasa } \\
\text { fiyatı }\end{array}$ & 39 & $\begin{array}{l}\text { emek } \\
\text { miktarı }\end{array}$ & 27 \\
\hline merkez bankası & 153 & $\begin{array}{l}\text { para } \\
\text { politikası }\end{array}$ & 67 & $\begin{array}{l}\text { AD } \\
\text { (k1saltma } \\
\text { ) }\end{array}$ & 38 & endüstri & 27 \\
\hline $\begin{array}{l}\text { toplam } \\
\text { harcamalar }\end{array}$ & 151 & istikrar & 66 & $\begin{array}{l}\text { devlet } \\
\text { harcamal } \\
\text { ar1 }\end{array}$ & 38 & $\begin{array}{l}\text { marjinal } \\
\text { tasarruf } \\
\text { eğilimi }\end{array}$ & 27 \\
\hline
\end{tabular}




\begin{tabular}{|c|c|c|c|c|c|c|c|}
\hline $\begin{array}{ll}\text { talep } & \text { edilen } \\
\text { miktar } & \end{array}$ & 143 & ortalama & 65 & $\begin{array}{l}\text { firsat } \\
\text { maliyeti }\end{array}$ & 38 & $\begin{array}{l}\text { üretim } \\
\text { maliyeti }\end{array}$ & 27 \\
\hline arz & 141 & endeks & 63 & pahalı & 38 & dış dünya & 26 \\
\hline üretici & 137 & malzeme & 62 & $\begin{array}{l}\text { denge } \\
\text { toplam } \\
\text { gelir } \\
\text { düzeyi }\end{array}$ & 37 & istatistik & 26 \\
\hline politika & 136 & $\begin{array}{l}\text { ödemeler } \\
\text { dengesi }\end{array}$ & 61 & iktisatçı & 37 & net ihracat & 26 \\
\hline toplam gelir & 136 & $\begin{array}{l}\text { para } \\
\text { miktarı }\end{array}$ & 61 & reel gelir & 37 & $\begin{array}{l}\text { pozitif } \\
\text { dışsallık }\end{array}$ & 26 \\
\hline döviz kuru & 134 & $\begin{array}{l}\text { arz edilen } \\
\text { miktar }\end{array}$ & 59 & $\begin{array}{l}\text { talep } \\
\text { esnekliği }\end{array}$ & 37 & rant & 26 \\
\hline fiyat düzeyi & 132 & dişsallık & 58 & ara mal & 36 & $\begin{array}{l}\text { toplam } \\
\text { tasarruflar }\end{array}$ & 26 \\
\hline girdi & 129 & $\begin{array}{l}\text { talebin } \\
\text { fiyat } \\
\text { esnekliği }\end{array}$ & 58 & $\begin{array}{l}\text { fiyat } \\
\text { farklılaştı } \\
\text { rması }\end{array}$ & 36 & $\begin{array}{l}\text { cari } \\
\text { işlemler } \\
\text { dengesi }\end{array}$ & 25 \\
\hline iş gücü & 129 & $\begin{array}{l}\text { denge } \\
\text { fiyatı }\end{array}$ & 57 & $\begin{array}{l}\text { harcanabi } \\
\text { lir gelir }\end{array}$ & 36 & $\begin{array}{l}\text { döviz } \\
\text { miktarı }\end{array}$ & 25 \\
\hline ödeme & 129 & $\begin{array}{l}\text { oligopol } \\
\text { piyasas1 }\end{array}$ & 57 & $\begin{array}{l}\text { mal ve } \\
\text { hizmet } \\
\text { üretimi }\end{array}$ & 36 & $\begin{array}{l}\text { marjinal } \\
\text { sosyal } \\
\text { fayda }\end{array}$ & 25 \\
\hline emek & 126 & $\begin{array}{l}\mathrm{AE} \\
\text { (k1saltma } \\
\text { ) }\end{array}$ & 56 & $\begin{array}{l}\text { toplam } \\
\text { maliyet }\end{array}$ & 36 & $\begin{array}{l}\text { negatif } \\
\text { dışsallık }\end{array}$ & 25 \\
\hline reel faiz & 125 & $\begin{array}{l}\text { iktisadi } \\
\text { büyüme }\end{array}$ & 55 & bileşim & 35 & $\begin{array}{l}\text { ürün } \\
\text { piyasas1 }\end{array}$ & 25 \\
\hline $\begin{array}{l}\text { tüketim } \\
\text { harcamaları }\end{array}$ & 121 & $\begin{array}{l}\text { nominal } \\
\text { GSYİH }\end{array}$ & 55 & $\begin{array}{l}\text { denge } \\
\text { miktarı }\end{array}$ & 35 & fiyat artışı & 24 \\
\hline döviz & 119 & $\begin{array}{l}\text { reel döviz } \\
\text { kuru }\end{array}$ & 55 & $\begin{array}{l}\text { döviz } \\
\text { talebi }\end{array}$ & 35 & & \\
\hline tam istihdam & 118 & kriz & 54 & $\begin{array}{l}\text { gayri safi } \\
\text { yurt içi } \\
\text { hâsıla } \\
\text { deflatörü }\end{array}$ & 35 & & \\
\hline toplam arz & 115 & $\begin{array}{l}\text { ticari } \\
\text { banka }\end{array}$ & 53 & maaş & 35 & & \\
\hline
\end{tabular}




\section{İşletme}

\begin{tabular}{|c|c|c|c|c|c|c|c|}
\hline $\begin{array}{c}\text { Sözcük/ } \\
\text { Terim }\end{array}$ & Sıklık & $\begin{array}{c}\text { Sözcük/ } \\
\text { Terim }\end{array}$ & Siklık & $\begin{array}{c}\text { Sözcük/ } \\
\text { Terim }\end{array}$ & Sıklık & $\begin{array}{c}\text { Sözcük/ } \\
\text { Terim }\end{array}$ & Sıklık \\
\hline işletme & 3377 & dağıtım & 64 & $\begin{array}{c}\text { işletme } \\
\text { yöneticisi }\end{array}$ & 28 & $\begin{array}{l}\text { finansal } \\
\text { yönetim }\end{array}$ & 19 \\
\hline faaliyet & 541 & işletmeci & 62 & nakit akış1 & 28 & güvenlik & 19 \\
\hline örgüt & 479 & $\begin{array}{l}\text { üretim } \\
\text { süreci }\end{array}$ & 61 & $\begin{array}{c}\text { sektörel } \\
\text { çevre }\end{array}$ & 28 & inovasyon & 19 \\
\hline müşteri & 407 & $\begin{array}{l}\text { büyük } \\
\text { işletme }\end{array}$ & 60 & ticari & 28 & kitle & 19 \\
\hline ürün & 395 & $\begin{array}{c}\text { işletme } \\
\text { faaliyetle } \\
\text { ri }\end{array}$ & 60 & $\begin{array}{c}\text { üretim } \\
\text { biçimleri }\end{array}$ & 28 & $\begin{array}{l}\text { klasik } \\
\text { yönetim }\end{array}$ & 19 \\
\hline ihtiyaçlar & 381 & $\begin{array}{c}\text { performa } \\
\text { ns }\end{array}$ & 60 & değerleme & 27 & teşvik & 19 \\
\hline çalışan & 377 & çıktı & 57 & genel çevre & 27 & toptan & 19 \\
\hline yönetici & 345 & paydaş & 57 & örgütsellik & 27 & yeni mamul & 19 \\
\hline $\begin{array}{c}\text { kaynak } \\
\text { (üretim } \\
\text { fak.) }\end{array}$ & 314 & dış çevre & 54 & firsat & 26 & iş gören & 18 \\
\hline yönetim & 299 & $\begin{array}{l}\text { işletme } \\
\text { yönetimi }\end{array}$ & 52 & iş yeri & 26 & $\begin{array}{l}\text { kitlesel } \\
\text { üretim }\end{array}$ & 18 \\
\hline çevre & 293 & iş birliği & 51 & $\begin{array}{l}\text { işletme } \\
\text { çevresi }\end{array}$ & 26 & nakit çıkışı & 18 \\
\hline pazar & 288 & $\begin{array}{c}\text { örgütlem } \\
\mathrm{e}\end{array}$ & 51 & liderlik & 26 & $\begin{array}{c}\text { rekabet } \\
\text { ortamı }\end{array}$ & 18 \\
\hline satış & 279 & $\begin{array}{c}\text { aşamalilı } \\
\mathrm{k}\end{array}$ & 50 & perakende & 26 & ambalaj & 17 \\
\hline fonksiyon & 266 & finansal & 50 & anlaşma & 25 & $\begin{array}{l}\text { at1l üretim } \\
\text { kapasitesi }\end{array}$ & 17 \\
\hline $\begin{array}{c}\text { insan } \\
\text { kaynakları }\end{array}$ & 244 & $\begin{array}{l}\text { küçük } \\
\text { işletme }\end{array}$ & 50 & beşeri & 25 & $\begin{array}{c}\text { beşerî } \\
\text { kaynaklar }\end{array}$ & 17 \\
\hline verimlilik & 221 & eğilim & 48 & doğal çevre & 25 & $\begin{array}{l}\text { ekonomik } \\
\text { çevre }\end{array}$ & 17 \\
\hline
\end{tabular}




\begin{tabular}{|c|c|c|c|c|c|c|c|}
\hline pazarlama & 201 & $\begin{array}{l}\text { ürün ve } \\
\text { hizmetler }\end{array}$ & 48 & hiyerarşi & 25 & geribildirim & 17 \\
\hline yatırım & 199 & tedarik & 47 & pazar payı & 25 & $\begin{array}{c}\text { insan } \\
\text { ihtiyaçları } \\
\text { ve istekleri }\end{array}$ & 17 \\
\hline kuruluş & 172 & misyon & 45 & resmî daire & 25 & iş güvenliği & 17 \\
\hline şirket & 154 & tedarikçi & 44 & iç çevre & 24 & kamuoyu & 17 \\
\hline büyüme & 152 & alt sistem & 43 & kâra geçiş & 24 & $\begin{array}{c}\text { ödüllendir } \\
\text { me }\end{array}$ & 17 \\
\hline personel & 139 & marka & 43 & nicelik & 24 & $\begin{array}{c}\text { pay } \\
\text { senetleri }\end{array}$ & 17 \\
\hline kalite & 134 & standart & 43 & tutum & 24 & $\begin{array}{l}\text { stratejik } \\
\text { amaçlar }\end{array}$ & 17 \\
\hline mamul & 129 & alternatif & 41 & yasal çevre & 24 & $\begin{array}{c}\text { uluslararası } \\
\text { işletme }\end{array}$ & 17 \\
\hline yaklaşım & 129 & $\begin{array}{c}\text { koordinas } \\
\text { yon }\end{array}$ & 41 & yatırımc1 & 24 & $\begin{array}{c}\text { üretim } \\
\text { kapasitesi }\end{array}$ & 17 \\
\hline $\begin{array}{l}\text { halkla } \\
\text { ilişkiler }\end{array}$ & 127 & uzman & 39 & $\begin{array}{c}\text { çalışma } \\
\text { sermayesi }\end{array}$ & 23 & atölye & 16 \\
\hline planlama & 127 & ast & 38 & $\begin{array}{c}\text { küreselleşm } \\
\text { e }\end{array}$ & 23 & avantaj & 16 \\
\hline girişimci & 122 & $\begin{array}{c}\text { kalite } \\
\text { kontrol } \\
\text { çemberi }\end{array}$ & 38 & $\begin{array}{c}\text { pazarlama } \\
\text { karması }\end{array}$ & 23 & $\begin{array}{l}\text { çok uluslu } \\
\text { işletme }\end{array}$ & 16 \\
\hline ücret & 122 & $\begin{array}{l}\text { üretim } \\
\text { sistemi }\end{array}$ & 38 & hissedar & 22 & $\begin{array}{c}\text { finansal } \\
\text { analiz }\end{array}$ & 16 \\
\hline rekabet & 117 & $\begin{array}{l}\text { hedef } \\
\text { kitle }\end{array}$ & 37 & imaj & 22 & $\begin{array}{c}\text { örgüt } \\
\text { kültürü }\end{array}$ & 16 \\
\hline hammadde & 115 & $\begin{array}{c}\text { potansiye } \\
1\end{array}$ & 37 & $\begin{array}{c}\text { insan } \\
\text { kaynakları } \\
\text { yönetimi }\end{array}$ & 22 & süreklilik & 16 \\
\hline kapasite & 99 & bileşen & 36 & kişisel satış & 22 & $\begin{array}{c}\text { üst kademe } \\
\text { yönetimi }\end{array}$ & 16 \\
\hline istek & 95 & $\begin{array}{l}\text { dağıtım } \\
\text { kanalları }\end{array}$ & 36 & net kâr & 22 & evrensellik & 15 \\
\hline
\end{tabular}




\begin{tabular}{|c|c|c|c|c|c|c|c|}
\hline analiz & 94 & $\begin{array}{c}\text { maddi } \\
\text { (ekonomi } \\
\text { k) }\end{array}$ & 36 & satın alma & 22 & iş analizi & 15 \\
\hline etik & 92 & $\begin{array}{c}\text { sanayi } \\
\text { devrimi }\end{array}$ & 36 & imalat & 21 & $\begin{array}{c}\text { kapasite } \\
\text { kullanım } \\
\text { oranı }\end{array}$ & 15 \\
\hline $\begin{array}{c}\text { organizasyo } \\
\mathrm{n}\end{array}$ & 84 & sendika & 36 & itibar & 21 & net satış & 15 \\
\hline $\begin{array}{c}\text { birim } \\
\text { (bölüm) }\end{array}$ & 79 & $\begin{array}{c}\text { işletme } \\
\text { fonksiyo } \\
\text { nları }\end{array}$ & 35 & $\begin{array}{c}\text { başarı } \\
\text { değerleme }\end{array}$ & 20 & otomasyon & 15 \\
\hline sektör & 78 & $\begin{array}{c}\text { motivasy } \\
\text { on }\end{array}$ & 35 & hacim & 20 & $\begin{array}{c}\text { pazarlama } \\
\text { araştırması }\end{array}$ & 15 \\
\hline nakit & 75 & finans & 34 & hedef pazar & 20 & emir & 14 \\
\hline risk & 75 & $\begin{array}{l}\text { örgüt } \\
\text { yap1s1 }\end{array}$ & 34 & $\begin{array}{c}\text { iş } \\
\text { değerleme }\end{array}$ & 20 & $\begin{array}{c}\text { faaliyet } \\
\text { alanı }\end{array}$ & 14 \\
\hline rakip & 73 & $\begin{array}{l}\text { nakit } \\
\text { girişi }\end{array}$ & 33 & iş etiğ $\mathrm{i}$ & 20 & $\begin{array}{c}\text { finansal } \\
\text { durum }\end{array}$ & 14 \\
\hline $\begin{array}{l}\text { araştırma- } \\
\text { geliştirme } \\
\text { (fonk.) }\end{array}$ & 70 & çıkar & 32 & $\begin{array}{l}\text { işletme } \\
\text { amaçları }\end{array}$ & 20 & $\begin{array}{c}\text { geri } \\
\text { besleme }\end{array}$ & 14 \\
\hline fabrika & 70 & girişim & 32 & küresel & 20 & iş bölümü & 14 \\
\hline strateji & 70 & siyasal & 31 & propaganda & 20 & $\begin{array}{c}\text { kamu } \\
\text { işletmesi }\end{array}$ & 14 \\
\hline $\begin{array}{c}\text { sosyal } \\
\text { sorumluluk }\end{array}$ & 69 & $\begin{array}{l}\text { çalışma } \\
\text { hayatı }\end{array}$ & 29 & $\begin{array}{c}\text { sermaye } \\
\text { piyasaları }\end{array}$ & 20 & patent & 14 \\
\hline arac1 & 68 & $\begin{array}{c}\text { pazarlam } \\
\text { a } \\
\text { iletişimi }\end{array}$ & 29 & sipariş & 20 & $\begin{array}{c}\text { ekonomik } \\
\text { yap1 }\end{array}$ & 13 \\
\hline eleman & 65 & yasal & 29 & $\begin{array}{c}\text { alt kademe } \\
\text { yönetimi }\end{array}$ & 19 & $\begin{array}{c}\text { etik } \\
\text { davranış }\end{array}$ & 13 \\
\hline
\end{tabular}

Genel Muhasebe

\begin{tabular}{cccccccc}
\hline $\begin{array}{c}\text { Sözcük/ } \\
\text { Terim }\end{array}$ & Sıklık & $\begin{array}{c}\text { Sözcük/ } \\
\text { Terim }\end{array}$ & Sıklık & $\begin{array}{c}\text { Sözcük/ } \\
\text { Terim }\end{array}$ & Sıklık & $\begin{array}{c}\text { Sözcük/ } \\
\text { Terim }\end{array}$ & Sıklık \\
\hline hesap & 2557 & alıcı & 128 & tahsil & 75 & sayım & 49 \\
\hline
\end{tabular}




\begin{tabular}{|c|c|c|c|c|c|c|c|}
\hline kayit & 775 & hisse senedi & 125 & belge & 72 & dönem kârı & 48 \\
\hline borç & 700 & ortak & 122 & $\begin{array}{c}\text { dönen } \\
\text { varlıklar }\end{array}$ & 72 & $\begin{array}{c}\text { finansman } \\
\text { giderleri }\end{array}$ & 48 \\
\hline alacak & 689 & aktif & 118 & defter & 71 & $\begin{array}{c}\text { banka } \\
\text { kredisi }\end{array}$ & 47 \\
\hline gider & 576 & bedel & 118 & $\begin{array}{l}\text { dönem içi } \\
\text { (işlem) }\end{array}$ & 71 & $\begin{array}{c}\text { devreden } \\
\text { KDV }\end{array}$ & 47 \\
\hline tutar & 507 & tahvil & 117 & $\begin{array}{c}\text { genel } \\
\text { yönetim } \\
\text { giderleri }\end{array}$ & 70 & $\begin{array}{c}\text { bağlı } \\
\text { ortaklıklar }\end{array}$ & 45 \\
\hline $\begin{array}{c}\text { katma } \\
\text { değer } \\
\text { vergisi }\end{array}$ & 489 & $\begin{array}{c}\text { öz } \\
\text { kaynaklar }\end{array}$ & 106 & $\begin{array}{l}\text { yardimcı } \\
\text { hesaplar }\end{array}$ & 68 & hâsılat & 45 \\
\hline dönem & 457 & $\begin{array}{l}\text { alacak } \\
\text { senedi }\end{array}$ & 104 & alacaklı & 66 & fiş & 44 \\
\hline varlık & 424 & $\begin{array}{l}\text { büyük } \\
\text { defter }\end{array}$ & 103 & $\begin{array}{l}\text { maddi duran } \\
\text { varlıklar }\end{array}$ & 66 & karşılık & 43 \\
\hline taraf & 395 & peşin & 103 & fatura & 65 & $\begin{array}{c}\text { nominal } \\
\text { değer }\end{array}$ & 42 \\
\hline maliyet & 376 & $\begin{array}{c}\text { borç } \\
\text { senetleri }\end{array}$ & 102 & bakiye & 62 & öz sermaye & 42 \\
\hline banka & 356 & aktarma & 101 & borçlu & 62 & $\begin{array}{l}\text { yabanc1 } \\
\text { kaynak }\end{array}$ & 42 \\
\hline kasa & 348 & $\begin{array}{c}\text { gelir } \\
\text { tablosu }\end{array}$ & 96 & kalan & 62 & gelir hesabı & 41 \\
\hline $\begin{array}{c}\text { değer } \\
\text { (ekonomi } \\
\text { k) }\end{array}$ & 335 & fon & 92 & kasa hesabı & 62 & yabancı para & 41 \\
\hline $\begin{array}{c}\text { amortism } \\
\text { an }\end{array}$ & 334 & hesap grubu & 89 & kalem & 61 & alınan çekler & 40 \\
\hline kâr & 319 & bono & 88 & gider hesabı & 60 & $\begin{array}{c}\text { fon akım } \\
\text { tablosu }\end{array}$ & 40 \\
\hline senet & 309 & iştirak & 88 & finansal tablo & 59 & komisyon & 40 \\
\hline $\begin{array}{l}\text { ticari } \\
\text { mallar }\end{array}$ & 297 & $\begin{array}{c}\text { amortisman } \\
\text { tutarı }\end{array}$ & 87 & mizan & 57 & kur & 40 \\
\hline sermaye & 284 & iskonto & 87 & pasif hesap & 57 & rapor & 40 \\
\hline
\end{tabular}




\begin{tabular}{|c|c|c|c|c|c|c|c|}
\hline bilanço & 281 & zarar & 87 & avans & 56 & tahakkuk & 40 \\
\hline işlem & 278 & çek & 86 & $\begin{array}{c}\text { maliyet } \\
\text { bedeli }\end{array}$ & 56 & yevmiye & 40 \\
\hline $\begin{array}{c}\text { muhaseb } \\
\mathrm{e}\end{array}$ & 276 & ticari alacak & 86 & birikmiş & 55 & uzun vade & 39 \\
\hline vade & 244 & iade & 83 & $\begin{array}{c}\text { birikmiş } \\
\text { amortismanla } \\
\mathrm{r}\end{array}$ & 54 & depozito & 38 \\
\hline stok & 228 & net & 82 & kira & 53 & $\begin{array}{c}\text { dönem net } \\
\text { kârı }\end{array}$ & 38 \\
\hline $\begin{array}{c}\text { duran } \\
\text { varlıklar }\end{array}$ & 204 & teminat & 82 & $\begin{array}{c}\text { aralıklı } \\
\text { envanter } \\
\text { (yöntem) }\end{array}$ & 52 & faiz gelirleri & 38 \\
\hline faiz & 198 & envanter & 80 & $\begin{array}{l}\text { tek düzen } \\
\text { hesap planı }\end{array}$ & 52 & $\begin{array}{c}\text { maddi } \\
\text { olmayan } \\
\text { duran } \\
\text { varlıklar }\end{array}$ & 38 \\
\hline satici & 181 & alış & 79 & $\begin{array}{l}\text { işletme } \\
\text { sahibi }\end{array}$ & 51 & $\begin{array}{c}\text { finansal } \\
\text { nitelikli olay }\end{array}$ & 37 \\
\hline $\begin{array}{c}\text { dönem } \\
\text { sonu }\end{array}$ & 147 & $\begin{array}{c}\text { vergi usul } \\
\text { kanunu }\end{array}$ & 79 & ortaklık & 51 & nazım hesap & 37 \\
\hline kredi & 147 & $\begin{array}{l}\text { yevmiye } \\
\text { defteri }\end{array}$ & 78 & indirim & 50 & kısa vade & 36 \\
\hline $\begin{array}{c}\text { menkul } \\
\text { kıymetler }\end{array}$ & 136 & poliçe & 77 & borç kaydı & 49 & & \\
\hline
\end{tabular}

Kamu Maliyesi

\begin{tabular}{cccccccc}
\hline $\begin{array}{c}\text { Sözcük/ } \\
\text { Terim }\end{array}$ & Sıklık & $\begin{array}{c}\text { Sözcük/ } \\
\text { Terim }\end{array}$ & Sıklık & $\begin{array}{c}\text { Sözcük/ } \\
\text { Terim }\end{array}$ & Sıklık & $\begin{array}{c}\text { Sözcük/ } \\
\text { Terim }\end{array}$ & Sıklık \\
\hline vergi & 1207 & açık & 51 & dolaylı vergi & 25 & teşkilat & 18 \\
\hline devlet & 980 & $\begin{array}{c}\text { kamusal } \\
\text { mallar }\end{array}$ & 51 & adil & 24 & $\begin{array}{c}\text { üretim } \\
\text { faaliyeti }\end{array}$ & 18 \\
\hline bütçe & 551 & özel kesim & 51 & fert & 24 & $\begin{array}{c}\text { yatırım } \\
\text { malları }\end{array}$ & 18 \\
\hline
\end{tabular}




\begin{tabular}{|c|c|c|c|c|c|c|c|}
\hline $\begin{array}{c}\text { kamu } \\
\text { harcamal } \\
\text { arı }\end{array}$ & 416 & dilim & 50 & $\begin{array}{l}\text { orta vadeli } \\
\text { program }\end{array}$ & 24 & iç denetçiler & 17 \\
\hline hizmet & 350 & kesim & 49 & $\begin{array}{c}\text { baskı } \\
\text { grupları }\end{array}$ & 23 & $\begin{array}{c}\text { kamu } \\
\text { maliyesi }\end{array}$ & 17 \\
\hline harcama & 312 & $\begin{array}{c}\text { artan oranlı } \\
\text { vergi tarifesi }\end{array}$ & 48 & $\begin{array}{l}\text { büyük } \\
\text { buhran }\end{array}$ & 23 & tasarı & 17 \\
\hline birey & 227 & durgunluk & 48 & $\begin{array}{l}\text { ekonomik } \\
\text { istikrar }\end{array}$ & 23 & $\begin{array}{l}\text { azalan oranli } \\
\text { tarife }\end{array}$ & 16 \\
\hline $\begin{array}{l}\text { kaynaklar } \\
\text { (gelir) }\end{array}$ & 225 & vergi borcu & 48 & $\begin{array}{c}\text { kamu } \\
\text { ekonomisi }\end{array}$ & 23 & $\begin{array}{l}\text { devlet } \\
\text { borçları }\end{array}$ & 16 \\
\hline görüş & 171 & kalkınma & 47 & $\begin{array}{c}\text { muamele } \\
\text { vergisi }\end{array}$ & 23 & doğal tekel & 16 \\
\hline $\begin{array}{l}\text { kamu } \\
\text { kesimi }\end{array}$ & 151 & bütçe açı̆̆ 1 & 46 & $\begin{array}{l}\text { sosyal } \\
\text { güvenlik } \\
\text { kurumu }\end{array}$ & 23 & $\begin{array}{l}\text { fonksiyonel } \\
\text { sinıflandırm } \\
\text { a }\end{array}$ & 16 \\
\hline $\begin{array}{c}\text { kamu } \\
\text { hizmeti }\end{array}$ & 140 & kamu gideri & 46 & stratejik plan & 23 & $\begin{array}{c}\text { piyasa } \\
\text { başarısızlığı }\end{array}$ & 16 \\
\hline $\begin{array}{l}\text { kamu } \\
\text { gelirleri }\end{array}$ & 123 & $\begin{array}{l}\text { kaynak } \\
\text { dağılımı }\end{array}$ & 46 & tekel & 23 & tahsis & 16 \\
\hline malî & 122 & cetvel & 44 & bağış & 22 & $\begin{array}{c}\text { tam } \\
\text { istihdam } \\
\text { denge } \\
\text { düzeyi }\end{array}$ & 16 \\
\hline $\begin{array}{l}\text { millî } \\
\text { gelir }\end{array}$ & 119 & müdahale & 42 & $\begin{array}{c}\text { düşük gelir } \\
\text { grupları }\end{array}$ & 22 & $\begin{array}{c}\text { vergi } \\
\text { politikaları }\end{array}$ & 16 \\
\hline kurum & 116 & servet & 42 & özel ekonomi & 22 & $\begin{array}{c}\text { anayasal } \\
\text { iktisat } \\
\text { görüşü }\end{array}$ & 15 \\
\hline ödenek & 115 & vergi sistemi & 42 & $\begin{array}{c}\text { piyasa } \\
\text { ekonomisi }\end{array}$ & 22 & bireysellik & 15 \\
\hline $\begin{array}{l}\text { yükümlül } \\
\text { ük }\end{array}$ & 108 & bütçe kanunu & 41 & refah & 22 & $\begin{array}{c}\text { dolaysız } \\
\text { vergi }\end{array}$ & 15 \\
\hline $\begin{array}{l}\text { vergilem } \\
\mathrm{e}\end{array}$ & 107 & gayrimenkul & 41 & şerefiye & 22 & $\begin{array}{c}\text { egemenlik } \\
\text { hakk1 }\end{array}$ & 15 \\
\hline $\begin{array}{c}\text { finansma } \\
\mathrm{n}\end{array}$ & 106 & siyasi & 40 & tasnif & 22 & $\begin{array}{l}\text { en az geçim } \\
\text { indirimi }\end{array}$ & 15 \\
\hline
\end{tabular}




\begin{tabular}{|c|c|c|c|c|c|c|c|}
\hline $\begin{array}{c}\text { kamu } \\
\text { idareleri }\end{array}$ & 98 & tarife & 40 & $\begin{array}{c}\text { borç } \\
\text { yönetimi }\end{array}$ & 21 & gösterge & 15 \\
\hline $\begin{array}{c}\text { gelir } \\
\text { dağılımı }\end{array}$ & 95 & $\begin{array}{c}\text { kamu iktisadi } \\
\text { teşebbüsleri }\end{array}$ & 39 & $\begin{array}{c}\text { diş } \\
\text { borçlanma }\end{array}$ & 21 & iç denetim & 15 \\
\hline bakanlık & 94 & mükellef & 39 & $\begin{array}{c}\text { istikrar } \\
\text { programı }\end{array}$ & 21 & İMF & 15 \\
\hline belediye & 94 & $\begin{array}{c}\text { il özel } \\
\text { idareleri }\end{array}$ & 38 & muafiyet & 21 & $\begin{array}{c}\text { mal ve } \\
\text { hizmet alımı }\end{array}$ & 15 \\
\hline idare & 89 & vergi yükü & 37 & özel mallar & 21 & malî araçlar & 15 \\
\hline $\begin{array}{l}\text { vergi } \\
\text { oranı }\end{array}$ & 86 & özel sektör & 36 & $\begin{array}{c}\text { tam kamusal } \\
\text { mal ve } \\
\text { hizmetler }\end{array}$ & 21 & menkul & 15 \\
\hline maliye & 83 & iktisadi & 35 & buhran & 20 & mevzuat & 15 \\
\hline matrah & 83 & $\begin{array}{l}\text { klasik iktisadi } \\
\text { düşünce }\end{array}$ & 34 & kuram & 20 & optimal & 15 \\
\hline KMYKK & 77 & büro & 32 & $\begin{array}{c}\text { kurumlar } \\
\text { vergisi }\end{array}$ & 20 & sanayileşme & 15 \\
\hline kamu & 74 & dağglım & 32 & $\begin{array}{c}\text { perakende } \\
\text { satış vergisi }\end{array}$ & 20 & $\begin{array}{l}\text { sosyalist } \\
\text { görüş }\end{array}$ & 15 \\
\hline $\begin{array}{c}\text { maliye } \\
\text { politikası }\end{array}$ & 72 & seçmen & 32 & diş borç & 19 & $\begin{array}{c}\text { toplumsal } \\
\text { mal }\end{array}$ & 15 \\
\hline harç & 68 & genel bütçe & 31 & efektif talep & 19 & $\begin{array}{l}\text { uzun vadeli } \\
\text { borçlanma }\end{array}$ & 15 \\
\hline $\begin{array}{l}\text { merkezî } \\
\text { yönetim }\end{array}$ & 68 & $\begin{array}{c}\text { kamu } \\
\text { kuruluşları }\end{array}$ & 31 & $\begin{array}{c}\text { eksik } \\
\text { istihdam }\end{array}$ & 19 & $\begin{array}{c}\text { veraset ve } \\
\text { intikal } \\
\text { vergisi }\end{array}$ & 15 \\
\hline $\begin{array}{c}\text { zorunlulu } \\
\text { k }\end{array}$ & 68 & parlamento & 31 & gelir kaynağ1 & 19 & $\begin{array}{c}\text { vergi } \\
\text { mükellefi }\end{array}$ & 15 \\
\hline adalet & 67 & $\begin{array}{c}\text { ekonomik } \\
\text { faaliyet }\end{array}$ & 30 & iç borçlanma & 19 & $\begin{array}{c}\text { vergi } \\
\text { sorumlusu }\end{array}$ & 15 \\
\hline etkinlik & 66 & kazanç & 30 & mekanizma & 19 & $\begin{array}{c}\text { bütçe } \\
\text { komisyonu }\end{array}$ & 14 \\
\hline $\begin{array}{l}\text { vergi } \\
\text { geliri }\end{array}$ & 63 & $\begin{array}{l}\text { harcama } \\
\text { vergileri }\end{array}$ & 29 & $\begin{array}{c}\text { millî } \\
\text { ekonomi }\end{array}$ & 19 & $\begin{array}{c}\text { çarpan } \\
\text { katsayısı }\end{array}$ & 14 \\
\hline $\begin{array}{l}\text { devlet } \\
\text { bütçesi }\end{array}$ & 60 & Sayıştay & 29 & oy alışverişi & 19 & daralma & 14 \\
\hline
\end{tabular}




\begin{tabular}{|c|c|c|c|c|c|c|c|}
\hline mevcut & 60 & bürokrat & 28 & stagflâsyon & 19 & $\begin{array}{c}\text { demokratik } \\
\text { parlamenter } \\
\text { sistem }\end{array}$ & 14 \\
\hline $\begin{array}{c}\text { mevcut } \\
\text { kaynaklar }\end{array}$ & 59 & $\begin{array}{l}\text { finansman } \\
\text { kaynakları }\end{array}$ & 28 & tarh & 19 & & \\
\hline kurul & 56 & mali yıl & 28 & bütçe teklifi & 18 & & \\
\hline $\begin{array}{c}\text { yerel } \\
\text { yönetiml } \\
\text { er }\end{array}$ & 56 & $\begin{array}{c}\text { parafiskal } \\
\text { gelirler }\end{array}$ & 28 & $\begin{array}{c}\text { faaliyet } \\
\text { raporu }\end{array}$ & 18 & & \\
\hline $\begin{array}{c}\text { gelir } \\
\text { vergisi }\end{array}$ & 55 & resim & 28 & $\begin{array}{l}\text { mahalli } \\
\text { idareler }\end{array}$ & 18 & & \\
\hline hazine & 54 & satış fiyatı & 28 & $\begin{array}{c}\text { milli } \\
\text { savunma } \\
\text { hizmeti }\end{array}$ & 18 & & \\
\hline $\begin{array}{c}\text { vergi } \\
\text { matrahı }\end{array}$ & 53 & ödeme gücü & 27 & oylama & 18 & & \\
\hline yetkili & 53 & $\begin{array}{l}\text { yerinden } \\
\text { yönetim }\end{array}$ & 26 & $\begin{array}{c}\text { servet } \\
\text { vergileri }\end{array}$ & 18 & & \\
\hline
\end{tabular}

\section{Extended Abstract}

In our age, globalization and rigorous competition in labor markets and education have led people to reconsider their attitudes towards learning a foreign language for general or specific purposes. A general view that speaking more languages has a significant impact on increasing the employability of a person, making it easier and faster to progress, and having a successful business life, contributes to many young people prioritizing multilingualism (Davidko, 2011: 82). In addition, the employees and their employers, especially those employed in international business sectors, have attempted to close their deficits in this field by experiencing the advantages of specialization in a foreign language. In recent years in Turkey, it is observed that the work done for a language teaching for specific purposes. Language teaching for specific purposes is primarily an area for meeting academic and professional language needs. Word lists play an important role in teaching a language for a specific purpose. In teaching Turkish for specific purposes, it is important to determine the concepts and terms related to these fields (such as Medical Turkish, Economics Turkish, Educational Sciences Turkish) in order to teach in more specific areas. This study, seems important to provide a list of words they will need in the area for foreigners studying in Economics and Administrative Sciences in Turkey. It is thought that teaching the concepts and terms in the "First 1000 Words List" with field specific texts will be effective in meeting the language needs of students. 
Data of the study was obtained; included in the course contents of Uşak University Faculty of Economics and Administrative Sciences Department of Economics, Business Administration, Public Administration, Finance and Economics; from the 5 faculty members who teach common courses of these departments; from the course materials suggested by the faculty members. This study was carried out due to document analysis of qualitative research methods. In the document review phase, the curriculum of the departments of the Faculty of Economics and Administrative Sciences at Uşak University was examined. Curriculum of the Departments of Economics, Business Administration, Public Administration, Finance and Econometrics, where foreign students are educated, are provided from related departments and subjected to a detailed examination. As a result of the screening, it was seen that all of these departments were taught the courses Introduction to Economics, Introduction to Law, Business Administration, General Accounting and Public Finance and it was considered appropriate to create content through these common courses. The faculty members interviewed at this stage are experienced instructors who carry out these courses. The data obtained from the course materials examined in the study were analyzed in SPSS 19 program and word lists were created. The data of the study were collected by taking into consideration the interview form approach. In the first part of the applied form, questions are included about faculty members'; i) faculty on duty, ii) educational background, iii) teaching experience and iv) profession. In the second part there are questions related to i) the reading materials used in the courses, ii) the basic sources of the field, and iii) the area-specific words and terms.

Based on the data obtained, a study was conducted to create a word pool to determine the diversity of the area-specific words, phrases and terms in source books which faculty members use in their courses and recommend and to determine the frequency distribution of these. In accordance with the information received from the faculty members for the purpose of the study, field-specific resource books were provided and made into Microsoft Word files. Then the books were read one by one by the researcher. When the reading process is finished, it is planned to determine the usage frequency by loading the words, phrases and abbreviations in SPSS 19 package program. During the reading, the spaces between the words that form the phrases are deleted one by one in order to load the concepts or terms consisting of more than one word into the program and calculate its frequency. For example, the gap between the "açılış envanteri" phrase was deleted and an "açılışenvanteri" was obtained. The topics in the books are broken down into sections, short summaries of these sections, evaluation questions and sample newspaper articles are not included. Parts of texts divided into sections are processed in SPSS 19 package program and total number of words, phrases and abbreviations in the books were determined.

A total of 10869 words, phrases and terms were identified from the subject areas according to the result obtained from the word list creation study. It has been seen that there are repetitive words and terms within the 10869 number, which is taken into 
consideration in the close relationship between business, accounting, law, economics and finance fields and the partnerships between these disciplines. It is considered that a certain number of words and terms that are most frequently used within these words and terms should be determined and so the first 1000 words and terms (APPENDIX) have been determined. The first 1000 words and terms from 10869 vocabulary are determined by taking into account the ratios of the numbers obtained from each field and the word, phrase and term that is found to be repeated after the ranking is included in the list according to the frequency order in the related field. The frequency of usage of the word and term in which the word and term is used in more than one area is taken into consideration and the related word or term is considered as the most common in the subject area.

In this study, according to the academic language branch of teaching language for specific purposes, "The First 1000 List of Words" was prepared to meet the vocabulary needs of foreign students studying in the Faculty of Economics and Administrative Sciences. Such studies, the foreigners who came to Turkey for specific purposes are seen important in terms of providing solutions to some problems encountered in language learning process. Studies to be done by determining language needs of the foreigners who came to Turkey to study or to work will provide significant contributions to teaching Turkish as a foreign language. Teaching Turkish for specific purposes with these words and phrases; the preparation of this word list by analyzing the text content of the related field will improve vocabulary and term teaching more effectively, it will also help learners to become better equipped in their fields and to be more successful in their courses and scientific activities by using four language skills better in the educational environment. The use of words and phrases obtained from this study in language teaching; in addition to language learners, will also provide convenience to lecturers at the faculty, language for specific purpose course providers and any material preparers involved. Because the language learner in the field will know firstly what subjects, words and phrases to learn, and the teacher will know what to teach. Those who are conscious and whose goals are certain language learner and teacher will always be more successful. 